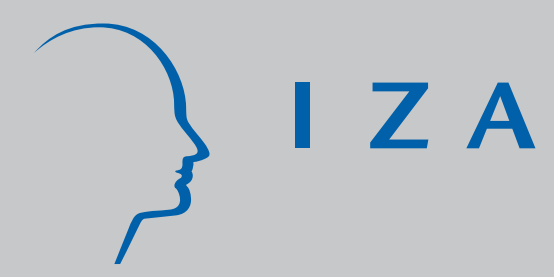

IZA DP No. 2170

Trade, Peace and Democracy: An Analysis of Dyadic Dispute

Solomon W. Polachek

Carlos Seiglie

J une 2006 


\title{
Trade, Peace and Democracy: An Analysis of Dyadic Dispute
}

\author{
Solomon W. Polachek \\ State University of New York at Binghamton \\ and IZA Bonn \\ Carlos Seiglie \\ Rutgers University
}
Discussion Paper No. 2170
June 2006

IZA
P.O. Box 7240
53072 Bonn
Germany

\author{
Phone: +49-228-3894-0 \\ Fax: +49-228-3894-180 \\ Email: iza@iza.org
}

\begin{abstract}
Any opinions expressed here are those of the author(s) and not those of the institute. Research disseminated by IZA may include views on policy, but the institute itself takes no institutional policy positions.
\end{abstract}

The Institute for the Study of Labor (IZA) in Bonn is a local and virtual international research center and a place of communication between science, politics and business. IZA is an independent nonprofit company supported by Deutsche Post World Net. The center is associated with the University of Bonn and offers a stimulating research environment through its research networks, research support, and visitors and doctoral programs. IZA engages in (i) original and internationally competitive research in all fields of labor economics, (ii) development of policy concepts, and (iii) dissemination of research results and concepts to the interested public.

IZA Discussion Papers often represent preliminary work and are circulated to encourage discussion. Citation of such a paper should account for its provisional character. A revised version may be available directly from the author. 


\section{ABSTRACT}

\section{Trade, Peace and Democracy: An Analysis of Dyadic Dispute}

At least since 1750 when Baron de Montesquieu declared "peace is the natural effect of trade," a number of economists and political scientists espoused the notion that trade among nations leads to peace. Employing resources wisely to produce one commodity rather than employing them inefficiently to produce another is the foundation for comparative advantage. Specialization based on comparative advantage leads to gains from trade. If political conflict leads to a diminution of trade, then at least a portion of the costs of conflict can be measured by a nation's lost gains from trade. The greater two nations' gain from trade the more costly is bilateral (dyadic) conflict. This notion forms the basis of Baron de Montesquieu's assertion regarding dyadic dispute. This paper develops an analytical framework showing that higher gains from trade between two trading partners (dyads) lowers the level of conflict between them. It describes data necessary to test this hypothesis, and it outlines current developments and extensions taking place in the resulting trade-conflict literature. Crosssectional evidence using various data on political interactions confirms that trading nations cooperate more and fight less. A doubling of trade leads to a $20 \%$ diminution of belligerence. This result is robust under various specifications, and it is upheld when adjusting for causality using cross-section and time-series techniques. Further, the impact of trade is strengthened when bilateral import demand elasticities are incorporated to better measure gains from trade. Because democratic dyads trade more than non-democratic dyads, democracies cooperate with each other relatively more, thereby explaining the "democratic peace" that democracies rarely fight each other. The paper then goes on to examine further extensions of the trade-conflict model regarding specific commodity trade, foreign direct investment, tariffs, foreign aid, country contiguity, and multilateral interactions.

JEL Classification: F01, F51, F59, D74

Keywords: trade, conflict, cooperation, interdependence, gains from trade, dyadic dispute, democratic peace, democracy

Corresponding author:

Solomon W. Polachek

Department of Economics

State University of New York at Binghamton

Binghamton, New York 13902-6000

USA

Email: Polachek@binghamton.edu

\footnotetext{
* We thank Jun (Jeff) Xiang for valuable research assistance, as well as Chuck Anderton and Todd Sandler for perceptive comments. Many of the findings reported here emanates from Polachek's collaborative research with Mark Gasiorowski, Judith McDonald, and John Robst. We thank each for their insights.
} 


\section{Introduction}

\subsection{The Setting: Monadic versus Dyadic Analysis}

On January 1, 1959, Fidel Castro assumed the leadership of Cuba, following a revolution that deposed General Fulgencio Batista. A little over one-year later, the then Soviet First Deputy Prime Minister Anastas Mikpyan negotiated a trade agreement to wean Cuba from its dependence on the United States. Soon thereafter, the Soviet Union and Cuba established full diplomatic relations. The United States responded with an economic and political offensive leading to the Bay of Pigs, and eventually the Cuban Missile Crisis. Whereas Cuban-US relations soured during this time period, the United States and Canada became more economically and politically tied.

Fast forward to 2005, Cuban-US economic and political relations were still poor; Cuba became less economically and politically reliant on Russia, but since the early 1990’s Cuba has received direct investment from Canada, as well as continued to engage in trade after 1959 and Canadian - Cuban political relations have been good. Not only has economic ties between the United States and Russia improved, but political relations between these two countries became relatively good. Canadian - US relations continue to be strong.

What do we learn from the above? First any one country (such as the United States, Russia, or Cuba) can have both cooperative and conflictive international relations at the same time; witness each country above has both friends and enemies. Second, economic and political relations are intrinsically intertwined. In this chapter, we argue that the "trade and conflict" literature is motivated by these two lessons. Any given country can be both cooperating with some countries and in a state of conflict with 
another set of nations at the same time. Furthermore, economic and political relations go hand-in-hand. Aside from the countries mentioned above, there are countless other examples. The question we want to address is why a particular country, like the United States has good relations with Canada yet poor relations with a country like Cuba; and why at the same time does a country like Cuba can have good relations with Canada, yet poor relations with the United States. Clearly looking at the attributes of only one country in isolation, rather than both the countries comprising the bilateral relationship (i.e., the dyad) would not provide a full answer. Nor would systemic variables, i.e., variables common to the entire international political system provide an answer, since they would not be able to explain how cooperation and hostility coexist simultaneously between two members of the system. For this reason, at a minimum, it makes sense to concentrate on dyads rather than countries as the unit of observation. In fact, this is precisely the approach of the conflict-trade literature, though now some have begun to extend the theory to incorporate multilateral situations. ${ }^{1}$

\subsection{Defining Peace: A Trade Theory Perspective ${ }^{2}$}

In the context of dyadic relations, we hope to show that conflict can be defined as trade gone awry. It is well known that nations (or for that matter other economic entities such as households) can raise their well-being through trade (if there is a difference in the relative prices each faces prior to trade). This increase in their welfare from an initial autarkic state is referred to as the "gains from trade." It results from gains due to specialization in production, which leads to higher levels of income and therefore greater consumption opportunities and from the opportunity to exchange at the lower prices, 
even if the level of production remains unchanged from its pre-trade level. Empirical evidence indicates the gains from trade can be substantial. For example, Acemoglu et al. (2003) demonstrate that access to the Atlantic is responsible for the rise of (Western) Europe between 1500 and 1850, and this is especially true for nations engaged in long distance oceanic trade.

But what happens when a particular economic entity's gains from trade are not as high as it thinks it should receive? Often in such a circumstance the entity uses force to achieve redistribution through various means of coercion. Using force to coerce is conflict. Since force can be viewed as a type of trade ('I'll be violent if you don't give me what I want"), conflict is a form, as well as symptom, of "trade gone awry." As such, conflict occurs when parties fight over economic rents. When conflict lasts over a long period, it is known as protracted conflict. From a normative perspective, the control and eradication of conflict is an area of interest in the field of defense economics and peace science. Economists in this area study ways to achieve peace through eradication of conflict, while also exploring the more positive aspect of assessing its impact on society. But to control and eradicate conflict, one must know how and why inadequate trade gains come about.

\subsection{Requirement for Peace: A Lasting Peace - Notions of a Stable Equilibrium}

Eradicating hostility and promoting cooperation is an important step leading to peace. One method of diminishing hostility and bringing about cooperation is by legalistic dictum often initiated by third parties. The problem is that attempts at peace imposed by others may be innately unstable, especially when the underlying differences originally separating the countries remain. For this reason, it seems reasonable that a 
viable peace is a natural peace based on mutual dependence. In his criticism of the Treaty of Versailles, Keynes (1920) argued that Germany be allowed to have economic relations with the rest of Europe or the prospects for peace would be dim. For example in The Economic Consequences of the Peace he writes "If we oppose in detail every means by which Germany or Russia can recover their material well-being, ...we must be prepared to face the consequences of such feelings." We similarly argue that only through mutual dependence can an equilibrium come about where peace remains solid and secure, so that neither party is motivated to change the status quo. Mutual dependence makes conflict more costly, and as such, it increases incentives for cooperation.

Probably many types of mutual dependence affect international relations. In many instances, political motivations form the basis of mutual dependence. When Willy Brandt became Foreign Minister in the Federal Republic of Germany in 1966, he developed the policy of Neue Ostpolitik (reconciliation between eastern and western Europe) eventually leading to a 1970 agreement accepting the borders of Berlin. Henry Kissinger pioneered the policy of détente that led to a considerable reduction in U.S.-Soviet tensions, including the SALT I strategic arms reduction talks, and the "opening" of China leading to an anti-Soviet Sino-American alliance. But underlying most instances of mutual dependence are economic considerations. Willy Brandt sought closer trading relations with Eastern Europe and the Soviet Union. This helped prop up the weak communist economies, but it also highlighted the contrasting wealth and poverty between the east and west and probably ultimately set the stage for reunification. Certainly from the Soviet viewpoint decelerating the arms race reduced the drain on social and economic resources, 
but equally America's economic vulnerability to nuclear holocaust was unimaginable. Certainly from China, Kissinger and Nixon sought trade in one of the fastest growing world markets. Finally, more recently, mutual dependence based on economics served as justification for the European nations to come together to form the European Union.

In this chapter, we concentrate on economic interdependence and in particular what political scientists refer to as "vulnerability interdependence" in the international relations literature [see Mansfield and Pollins (2001) for a discussion]. This type of interdependence attempts to capture the cost of rupturing economic relations with another country. In fact, most quantitative studies of interdependence and conflict concentrate solely on economic aspects because economic aspects are more easily measured. As will be explained later, most use bilateral trade (or some trade-related measure such as tradeshare or a trade-relative-to-GNP statistic) as the measure for interdependence, but even this is a simplification. As will be explained, theory predicts "gains from trade" to be the most relevant indicator of economic interdependence. However, because of the difficulty of measuring trade gains, almost all research uses some variation of trade level to measure mutual economic dependence. But before we jump ahead, we examine the trade (interdependence) - conflict model. ${ }^{3}$

\section{Modeling How Trade Affects Conflict and Cooperation}

The proposition that trade deters conflict has roots as far back as the sixteenth century. First, theologian philosophers such as Erasmus (1981) [Enchiridion Militis Christiani, the "Handbook of the Christian Soldier" originally published in 1503] realized that war was "bad." Later, the French monk Crucé (1623) sought international bodies to arbitrate international disputes. This point of view was later taken up by Rousseau (2005 
originally published circa 1756) who realized that using organizations designed to arbitrate disputes would bring nations closer through communication. Related to arbitration, Immanuel Kant (Perpetual Peace: A Philosophical Sketch, 1795) argued that perpetual peace could be achieved through appropriate governance in which all means used to wage war should be prohibited in order to establish mutual trust among nations. But whereas Kant believed mutual trust must be legislated, forty-five years earlier, in 1750, Baron de Montesquieu provided an economics approach to achieve mutual trust. He stated that "peace is the natural effect of trade" because "two nations who traffic with each other become reciprocally dependent" leading to "their union ... founded on their mutual necessities" [(1900, p. 316)]. Much later, British statesmen Cobden (1995, originally published in 1846), Bright (1883), as well as economists Angell (1913) and Viner (1937) espoused these same views. Perhaps, for this reason Hirschman (1945: v, xvi) emphasized 'the politics of foreign trade' by which he spelled out "the possibility of using trade as a means of political pressure ... in the pursuit of power." Cutting existing trade for political reasons reduces gains from trade, though these losses can be somewhat mitigated if other trading partners can be found. But even here, finding other trading partners is costly.

\subsection{An Economics Model of the "Peace-Through-Trade" Liberal Hypothesis}

\subsubsection{Verbal Explanation}

These notions about how mutual dependence leads to peace can be formalized. No individual produces everything he or she needs. Instead each individual finds it advantageous to specialize. Division of labor comes about because persons work at what they do best, and trade for what they produce in a relatively more expensive way. 
International trade occurs for the same reason. One country alone is not able to produce all it needs efficiently. A country is said to have a comparative advantage over another when it is relatively more productive in the production of a particular commodity. Comparative advantage enables both countries to increase their welfare through trade. Thus trade is welfare enhancing.

Define conflict to be an unfriendly political action from one country to another that is hostile enough to lead the second country to cease or at least diminish trade. Generally, loss of existing trade implies a welfare loss. It is these potential welfare losses that can deter conflict. More specifically, a country that is trading with another at international prices must be better off than in autarky, otherwise it would have chosen not to trade and instead face autarkic prices. Conflict reduces trade and forces the country towards prices that are closer to where they would be in autarky. Therefore, the more that conflict changes prices towards their pre-trade level the more countries will attempt to avoid conflict. This in a nutshell is the basis for the trade-conflict model.

\subsubsection{Mathematical Depiction ${ }^{4}$}

Polachek $(1980,1992)$ developed a framework to analyze the trade-conflict nexus. In his model, a country's preferences can be represented by a utility function over the consumption, C, of m-goods that are produced in a k-country world. Furthermore, each of these countries can initiate conflict or cooperation on any of the k-1 countries towards which the level of intensity is denoted by a $1 \mathrm{x}(\mathrm{k}-1)$ vector $Z$. Preferences for the level of conflict or cooperation to achieve outcomes deemed important by a country generate a derived demand for it. Furthermore, conflict has effects on the terms of trade or prices in the world markets. 
Formally, a country seeks to maximize:

$$
U=U(C, Z)
$$

with $C=\left\{c_{1}, c_{2}, \ldots, c_{m}\right\}$ and. $Z=\left\{z_{1}, z_{2}, \ldots, z_{k-1}\right\}$.

In order to simplify the analysis, we assume that there are two commodities which are produced in the country, $q_{1}$ and $q_{2}$ with their respective levels of consumption and prices in the country denoted by $c_{1}, c_{2}$ and $p_{1}, p_{2}$, respectively. Assume that the country interacts with only one other country in the world and we denote the level of intensity directed at this country by $z$. Therefore, the utility function for the country's decisionmaker is now

$$
U\left(c_{1}, c_{2}, z\right)
$$

and is assumed to be defined based on the preferences of the entire population. ${ }^{5}$

In a one-period world, the budget constraint for the country is:

$$
p_{1} c_{1}+p_{2} c_{2}+p_{z} z=p_{1} q_{1}+p_{2} q_{2}
$$

where the cost of the resources used to generate conflict or cooperation is $p_{z}$. Conflict is assumed to affect prices. More specifically,

$$
p_{i}=p_{i}\left(z, z^{*}\right)
$$

where $z$ is the intensity of conflict or aggression of country 1 targeted at country 2 and $z^{*}$ is the level of aggression of country 2 towards 1 . Assuming that country 1 exports commodity 1 and imports commodity 2, conflict affects prices in the following manner:

$$
\frac{\partial p_{1}}{\partial z} \leq 0 \text { and } \frac{\partial p_{2}}{\partial z} \geq 0
$$


In other words, we assume that conflict directed towards the other country reduces or has no impact on the price the country obtains for its export commodity and increases or has no impact on the price the country pays for its imported goods. Greater conflict by the actor towards the target requires the actor to reduce the price of their exports to induce them to purchase the good and leads to them being charged a higher price for the imports from the target country. The smaller either country is, the smaller the impact that conflict will have on prices since the elasticity of demand for imports will be greater. In the extreme case, both countries are prices takers in the international market and the cost of trade diversion is negligible.

The problem for the actor country is to maximize equation (1') subject to their resource constraint and the country's level of technology. Figure 1 depicts the problem graphically. The production possibility curve for the country is given by $A B$ and in a world without conflict $(z=0)$, the country would choose to consume at $c^{* *}$ and produce at $Q^{* * *}$ when faced with the ratio, $p_{1} / p_{2}$ yielding a level of utility of $U_{1}$. If the actor chooses to allocate $z>0$ resources to conflict, then the country's consumption possibilities are reduced to $A^{\prime} B^{\prime}$ since there are less resources available for consumption and the terms of trade are worsened. We assume that the new equilibrium in the $c_{2} c_{1}$ space is given by $U_{2}$. The country trades off the gains from trade for the gains from engaging in conflict. Then the implicit cost of conflict is the lost gains from trade $U_{1}-U_{2}$ associated with decreased trade. ${ }^{6}$ Obviously, the greater the welfare loss the greater the costs of conflict, and the greater the incentive for cooperation, independent of the country's innate preference for peace. Even if conflict does not directly diminish trade, but instead leads to trade restrictions that ultimately affect the terms of trade, the 
same result applies. In this case, less desirable terms of trade result (e.g., a flatter terms of trade line in Figure 1) implying a new equilibrium and lower welfare. Again, the implicit price of conflict is the lost welfare associated with diminished trade brought about by conflict.

Algebraically, the problem for the actor country is to maximize:

$L=U\left(c_{1}, c_{2}, z\right)+\lambda\left[p_{1} q_{1}+p_{2} q_{2}-p_{1} c_{1}-p_{2} c_{2}-p_{z} z\right]$

by choosing the amount of consumption of the two goods and the level of conflict to initiate against the target country while taking into account the effects that this has on prices. One could think of the problem as being solved in two stages. In the first stage, individuals decide on the amounts to consume of the different commodities, yielding the composition of imports and exports. In the second stage, the government decides on the level of conflict, $z$, to undertake. We can rewrite the problem as

$$
\operatorname{Max} L=U\left(c_{1}, c_{2}, z\right)+\lambda\left[p_{1} x_{1}+p_{2} m_{2}-p_{z} z\right]
$$

where exports, $x_{1}=q_{1}-c_{1}$ and imports, $m_{2}=q_{2}-c_{2}$. The first order conditions are:

$$
\begin{aligned}
& \frac{\partial U}{\partial c_{1}}-\lambda p_{1}=0 \\
& \frac{\partial U}{\partial c_{2}}-\lambda p_{2}=0 \\
& \frac{\partial U}{\partial z}+\lambda\left[\left(x_{1}+p_{1} \frac{\partial x_{1}}{\partial p_{1}}\right) \frac{\partial p_{1}}{\partial z}+\left(m_{2}+p_{2} \frac{\partial m_{2}}{\partial p_{2}}\right) \frac{\partial p_{2}}{\partial z}-p_{z}\right]=0
\end{aligned}
$$


These can be rearranged as:

$$
\begin{aligned}
& \frac{\partial U}{\partial c_{1}} / \frac{\partial U}{\partial c_{1}}=\frac{p_{1}}{p_{2}} \\
& \frac{\partial U}{\partial z}=\lambda\left[p_{z}-\left(x_{1}+p_{1} \frac{\partial x_{1}}{\partial p_{1}}\right) \frac{\partial p_{1}}{\partial z}-\left(m_{2}+p_{2} \frac{\partial m_{2}}{\partial p_{2}}\right) \frac{\partial p_{2}}{\partial z}\right] .
\end{aligned}
$$

Equation (10) is the standard condition for utility maximization in the consumption of the two goods. Whereas, equation (11) is the additional condition that must be satisfied. The left hand side of this equation is the marginal benefit from engaging in conflictual activity. The marginal cost is given by the right hand side and includes the direct cost of allocating a unit of consumption to $\mathrm{z}$ evaluated at the price of $\mathrm{z}, p_{z}$, as well as the indirect cost of reduction in import and export revenues resulting from the changes in prices as a consequence of international conflict,

$$
\left(x_{1}+p_{1} \frac{\partial x_{1}}{\partial p_{1}}\right) \frac{\partial p_{1}}{\partial z}-\left(m_{2}+p_{2} \frac{\partial m_{2}}{\partial p_{2}}\right) \frac{\partial p_{2}}{\partial z} .
$$

Therefore, equation (11) describes the mechanism by which a country decides on the amount of belligerence. Since the bracketed term is the explicit cost as well as the implicit one of receiving less revenue for exports while at the same time having to pay more for imports, it represents the cost associated with extra hostility (MC). This term can be represented graphically (Figure 2) as an upward sloping curve whose position depends on the levels of imports and exports, $m_{2}$ and $x_{1}$. In equilibrium, this cost of 
hostility must just balance the welfare benefit of added hostility $\left(\frac{\partial U}{\partial z}\right)$ so that the intersection of the $\left(\frac{\partial U}{\partial z}\right)$ curve and the MC curve depicts the equilibrium conflict/cooperation. Note that equilibrium conflict/cooperation levels still arise even if hostility or cooperation implies no welfare gain $\left(\frac{\partial U}{\partial z}=0\right)$. In this case, optimal conflict is based purely on economic grounds at the point where the MC curve intersects the horizontal axis. If imports or exports are increased, the MC shifts up, thereby implying lower levels of conflict. Thus,

Proposition One: The greater is an actor country's level of trade with a target, the smaller the amount of conflict that the actor will have with the target country.

If international borrowing and lending is assumed not to be available, then conflict induces a change in optimal imports and exports. The more unfavorable the relative prices of trade induced by conflict, the more exports are forced to increase, and imports decrease. From the above one can show that welfare losses are largest, the more inelastic the import and exports demand and supply curves. Hence,

Proposition Two: The more inelastic (elastic) an actor country's import and export demand and supply to a target country, the smaller (larger) will be the amount of conflict initiated by the actor towards the target country.

There are other propositions that follow from the model. However, due to the lack of data for conducting the appropriate statistical tests, researchers generally 
concentrate on these two propositions, which form the basis of most tests of the conflicttrade model. Therefore, we hypothesize a relationship between bilateral international conflict and the welfare gains associated with bilateral trade. More precisely, the greater the welfare gains, the smaller the level of conflict that we expect. Since welfare gains increase with the level of trade, yet decrease with the import and export demand and supply elasticities, we argue that countries with the most trade (and the greatest gains from trade) have the most to lose from conflict. Ceteris paribus these countries have lesser amounts of conflict. Countries with the most elastic import demand and export supply curves gain the least from trade, and hence ceteris paribus, these countries engage in greater conflict.

To test these propositions, most empirical analyses concentrate solely on the conflict-trade relationship, but neglect gains from trade. As such, they utilize measures of conflict (which will be discussed later) and trade levels, and test for an inverse relationship. By limiting themselves strictly to trade levels, they implicitly assume each country's import demand and export supply curves are comparable. But clearly these import and export demand and supply curves may differ. Only a few studies get at actual gains from trade. Although imperfect, they do so by including information on import demand elasticity. We discuss more of the estimation problems that arise later in the chapter.

\subsubsection{Trade Gone Awry: Three Conditions For Inadequate Trade Gains}

There are at least three causes for inadequate trade gains. First, nations do not trade when possibly they should. Reduced trade because of tariffs would be an example. Second, two non-trading nations may be competing for the same trade, and hence the 
same pool of economic rents. Competition in oil sales leading OPEC members to cheat on cartel production allocations might be an example of this type condition. Third, trading partners may believe their particular terms of trade are inequitable. This generally arises when bilateral bargaining between nations determine price, but other systemic global forces determine other conditions regarding exchange.

Finally, we should note that not all theorists affirm that trade reduces conflict. Amongst these, some question whether both trading partners actually achieve positive gains from trade in many international transactions. If there are no gains from trade then conflict would not be mitigated. Others argue that trade gains provide an increase in real resources that can have a positive income effect, thereby providing an impetus for increased military spending. Finally, based on asymmetric information some argue that trade can increase conflict. We review each in turn below.

\subsection{Alternative Conflict-Trade Theories}

\subsubsection{Marxian-based Theories ${ }^{7}$}

Marxian-based theories contend that colonialism and imperialism go hand in hand with trade. They argue countries essentially use military force to expand trade. Viewed in this framework, trade implies an oppressor nation and an oppressed nation, with the powerful oppressor exploiting the weaker oppressed nation. Under this approach, since trade is coerced by the use or threat of force, it becomes involuntary leading to asymmetric strictly one-sided trade gains. One side wins all, and as such, the other side actually suffers major economic and other losses from trade.

Clearly a nation losing resources based on involuntary exploitative trade is far different than a nation engaged in mutually beneficial bilateral trade, where both sides 
gain. Both types of nations face far different circumstances. One gains from trade, and the other loses. But even a liberal theorist would find it reasonable for a nation to fight exploitation were trade gains really negative. In such a situation neither Marxian nor liberal theories contradict each other. The real question becomes whether trade is involuntary, and if so whether it exploits a nation thus rendering gains from trade to be negative, as Marxists claim; or conversely whether trade is mutually beneficial, as certainly most economists believe. Only if the former exploitation is true, can trade lead to conflict, but this circumstance is an empirical question - not a counterexample to the liberal hypothesis. Thus there is no contradiction, only the need for researchers to evaluate trade gains. But, according to some, even in the context of neoclassical economic models, positive gains from trade can lead to conflict

\subsubsection{Gains from trade and military expenditures}

Whereas the conflict-trade model uses a Ricardian $(1981,1817)$ framework to show how countries engage in cooperation to protect trade gains, another approach developed by Seiglie $(1992,1996,2005)$ and Findlay (2001) adopts the gains-from-trade framework to show how conflict can rise with trade. In these latter models, rather than trade partners acting cooperatively to protect trade gains, each trading partner utilizes newly acquired gains-from-trade wealth to purchase more of all goods and services, including military equipment. More specifically, as an economy opens to trade and real income rises, a country will spend more on weapons to protect these gains. Empirically, this leads to testing whether there is a positive association between the size of international trade (as a proxy for the gains from trade) and military spending. Indeed, historically nations used their navy to protect themselves from pirates, which probably 
was the navy's prime raison d'être. On the other hand, it is not clear that augmenting military expenditures to protect trade, or even to augment other aspects of a nation's security, implies more dyadic conflict.

Military expenditures, addressed by these theories, need not necessarily be equated with conflict. Although military equipment resulting from military expenditures often is used in combat, it can be employed for other purposes, such as augmenting national security. However, even if used for conflictive purposes, the resulting conflict most likely would not be directed towards trading partners, but more likely directed at third parties from whom protecting trade gains is not an issue. As such, gains-from-trade induced military expenditures would not contradict the liberal trade-conflict model that more trade increases cooperation, since any belligerence, if it even occurs, most likely would not be directed towards trading partners. Simply put, military expenditures are an aggregate measure encompassing far more than dyadic conflict. Indeed, bilateral interactions among trading partners should improve to protect the trade gains, which enable spending some of the gains from trade on higher military expenditures to ensure greater security. Thus theories propounding trade to induce higher military expenditures do not contradict the trade-conflict model. As will be illustrated next, the same is true for game theoretic models.

\subsubsection{Game-theory: Signalling Models}

In the typical game theory model, parties vie to split contested resources. As already indicated, trade produces gains, which must be divided between two (or more) trading partners. Accordingly, trade gains becomes the contested resource and game theory is invoked to determine how each party behaves to determine the division. But, in 
the process of dividing a given resource, it becomes obvious that what one party gains, the other loses, so that the process itself has a conflictive nature. In fact, Schelling (1960) and later on Hirshleifer (1995) view conflict in this manner. Thus to game theorists the logic is simple: first, trade creates trade gains; second, trade gains must be divided; finally, dividing trade gains leads to conflict. Following the logic through, trade leads to conflict [see Morrow $(1997,1999)$ for example].

Again there is no contradiction with the liberal trade-conflict model which states that trade yields more cooperation than conflict. Two issues are involved: (1) whether dividing trade gains necessarily yields conflict as game theoretic models imply, and (2) whether the conflict emanating from splitting trade gains outweighs the necessary cooperation needed to protect the trade, which created the gains in the first place.

Take the first issue. A country's output can be visualized by a productionpossibilities-frontier representing all goods and services a country can produce under autarky. Comparative advantage occurs when there exists differences in relative costs resulting from varying factor endowments or technology. Under such circumstances it pays for each country to trade by exporting what it produces most efficiently and importing what it produces less efficiently. Thus if country A has a comparative advantage in agriculture and country B in manufacturing, each can specialize; and both can be made better off. Clearly each country gains, but the extent of the gains are determined by relative prices. With only two countries and imperfect information about their preferences it might pay for each to send a signal to mislead the other in order to eke out a better terms of trade. Such gamesmanship can lead to conflict ex poste; but nevertheless, it does not pay to have so much conflict so as to deter trade, since such 
action eliminating trade would eradicate trade gains completely. This is essentially the conclusion reached by Krugman (1995). Thus even if (1) above is correct, dividing trade gains need not imply an amount of conflict that exceeds the amount of cooperation necessary to protect trade in the first place. But it is not obvious that game theory is even always relevant in splitting trade gains.

Trade gains are determined by prices. Clearly the higher the export price, the greater a country's revenues from selling its products if the commodity's demand is inelastic and as a result, the greater the trade gains, all else constant. In the world, prices are usually set in the market. Market determined prices mean that posturing for the best price is not a viable option for the typical (small) country, because the typical country must simply take prices as given. In this case there are no contested resources. Gains from trade are fixed, since each trading partner cannot change world prices. Indeed the only option is to take one's trade elsewhere, but here too the market basically sets the price. So game theory is essentially irrelevant, because except for countries with monopolistic power the market determines price.

Essentially there is no real contradiction between the above three approaches and the conflict-trade model itself. As such, because there is no contradiction, these three models cannot serve as an alternative explanation for the non-trivial instances of a positive trade-conflict relationship. For this reason, one needs to better understand the conflict-trade model and its implications, in order to better understand the seemingly contradictory findings relating trade and conflict. The remainder of this chapter examines the empirical findings in the conflict-trade literature. 


\section{Testing the Theory}

\subsection{Data}

\subsubsection{Measuring Conflict}

Usually when one thinks of conflict, one thinks of large economic entities such as countries or groups of countries. In large-scale conflicts that take place among sizable entities, the degree of destruction is overwhelming. Over 34 million were injured in World War II, over 22 million died, and over \$15 trillion (2004 dollars) were expended militarily. However, in the original conflict literature by Richardson (1960), the inventor of arms race models and whose work is the forerunner of modern peace economics research, conflict was defined more broadly even to include everyday criminal activities. Richardson understood that conflict can take many forms.

\subsubsection{War Data}

As devastating as they may be, wars are actually relatively rare, and hard to define. Currently there are numerous data sets that compile information on wars. Perhaps the oldest is Richardson's (1960), containing data on 779 deadly quarrels during 18091949. Wright's (1942) A Study of War contains data on approximately 300 wars between 1480 and 1941. Other studies include Singer and Small (1972) Wages of War data, containing data on 79 interstate wars (more than 1000 fatalities) between 1816 and 1980 . These data are continually updated under the Correlates of War Project and now contain information on other relevant variables. Also there are Levy's (1983) major power war study, the Stockholm International Peace Research Institute data (which can be obtained from its annual yearbook containing armed conflict data), and the Gochman-Maoz (1984) 
militarized dispute data containing interstate events involving threats or actual use of force. Many of these data are available on the internet.

\subsubsection{Militarized Interstate Dispute (MIDS) Data}

One problem is that wars are particularly intensive but relatively rare. The number dead or wounded varies with technology as well as country size. Similarly war data deal only with extreme hostility. They neglect acts less hostile than war as well as instances of cooperation. Militarized interstate dispute data from the Correlates of War (COW) project contain 2331 interstate disputes (conflicts in which one or more states threaten, display, or use force against one or more other states) between 1816 and 2001. But even these military dispute data represent a fraction of all interactions. Other data such as defense expenditures can indicate general hostility levels, yet defense expenditures need not reflect hostility at all since such expenditures could be viewed as a warning to other nations, and thus serve more as a measure of deterrence. Alternatively, defense expenditures can measure repression of domestic unrest. Similarly such measures as U.N. voting data are often deemed inadequate since they might measure political attitudes or the results of foreign aid investments rather than actual country conflict.

\subsubsection{Events Data}

To alleviate some of these deficiencies several scholars have taken a different approach by compiling events data. Events data comprise bilateral interactions reported in newspapers. While clearly not all interactions are reported in newspapers, these type of data have the advantage of being able to incorporate conflictive interactions short of war, as well as cooperative type political exchanges. McClelland (1999) was the first to 
compile events data in the 1960s. His World Events Interaction Survey (WEIS) uses information solely from the New York Times. McClelland (1999) originally distinguished 22 classes and seven types of bilateral actions [Azar and Ben-Dak, (1975)]. Shortly thereafter, Azar (1980) classified information from almost 50 newspapers from all over the world to report on bilateral interactions of 115 countries from 1948 to 1978 in his Cooperation and Peace Data Bank (COPDAB) ${ }^{8}$ Finally, more recent events data are computer driven. They use computer software to read and machine-code wire service reports, particularly Reuters. Originally developed at the University of Kansas, these data are known as the Kansas Events Data Study (KEDS). Beginning in 1992 a group of researchers headed by Doug Bond at Harvard University's Center for International Affairs joined with scholars at the University of Kansas. The Harvard team developed a protocol to classify events, which they called PANDA (Protocol for the Assessment of Nonviolent Direct Action). Subsequently, Virtual Research Associates, Inc. was established in 1996. They later partnered with several University-based research teams to expand their original protocol. This second-generation protocol is called IDEA (Integrated Data for Events Analysis). Currently, the Harvard-MIT Virtual Data Center distributes historical events data developed by VRA for use by scholars.

COPDAB: The Conflict and Peace Data Bank (COBDAB) is an extensive longitudinal collection of about one million daily events reported from forty- seven newspaper sources between 1948 and 1978 [Azar, 1980)]. These events are coded on a 15-point scale representing different kinds of conflict and cooperation. COPDAB events in categories 1 (voluntary unification) through 7 (minor official exchanges) represent cooperation. Categories 9 (mild verbal expressions displaying discord) through 15 (extensive war acts 
causing deaths) represent conflict. Included in COPDAB is a numerical weighting of the amount of conflict and cooperation as determined by 18 scholars and practitioners of international relations. These are given in Table 1. To come up with a composite number, Polachek (1980) defined NETF as the weighted (taken from Table 1) frequency of conflictive events (those in category 9 to 15) minus the weighted frequency of cooperative events (those in category 1 to 7). Here, a negative value of NETF implies that more (weighted) cooperation occurs than conflict, hence that on balance international interactions would be more cooperative than hostile. There are over 105 countries in the sample, and hence about 11 thousand possible dyadic interactions per year.

WEIS: The World Events Interaction Survey (WEIS) data is a compilation of bilateral international interactions occurring between 1966-1992 reported in the New York Times. They are coded using IDEA (Integrated Data for Events Analysis). This framework fits every reported event into one of 22 broad categories ranging from extending aid (code 7) to military assaults using force (code 22). Specific definitions for each type of cooperation and conflict event are given in Table 2, Column 2 (labeled IDEA). They are weighted based on Goldstein's (1992) scale that converts the IDEA code to one that better classifies each event's intensity. In order to be consistent with COPDAB, we multiply Goldstein's weights by minus one to give conflictive events positive values and cooperative events negative values. Thus, as can be seen from the Table 2 , the positive scale values represent conflict and the negative ones cooperation, while zeros are basically natural disasters and neutral social activities. The maximum positive value is 10, which corresponds to extreme conflict cases. Negative values indicate cooperation. The maximum negative value is -8.3 . Since the scale includes 55 categories, it makes the 
use of a count model inappropriate. It is possible to divide these into smaller subcategories, but the problem is how to capture nuance differences within each category. A more useful method is to compute the weighted sum of all events for each dyad by year (weighted by the modified Goldstein scale for each type of event form). Given that their signs differentiate conflict and cooperation, a positive weighted sum means net conflict. Conversely, a negative sign implies net cooperation.

Virtual Research Associates (VRA) Data: The Virtual Research Associates (VRA) data are derived from dyadic events reported in the wire services. Rather than being read and transcribed from newspapers, they are based on computer driven formulae that analyze the first sentence of each news report. From these first sentences, the computer determines an actor, a target as well as an action [see King and Lowe (2003) for examples and more details]. This event data set is coded by IDEA so that the classification scheme is comparable to that used in WEIS. As with WEIS, the weighted sum of all events for each dyad by year, weighted by the Goldstein scale for each type of event is computed.

Because the scaling codes are the same for VRA and WEIS it makes sense to compare conflict measures for these two data sets. To do so, we take the average severity weighted level of conflict and cooperation using the Goldstein scale weights given in Table 2. Note that the WEIS data is from 1966-1992 and the VRA is from 1990-2001. The average value for WEIS for net conflict was -0.82 during the recorded period while for VRA it was 0.55 . A negative number indicates more conflict than cooperation, while a positive number indicates more cooperation. This is the case for the VRA data. Apparently in the 1990 s there was more cooperation than conflict. Although, the conflict- 
cooperation scale differs the same is also true for COPDAB data. So it appears that between 1948 and 1978 there also was more cooperation reported than conflict.

On the other hand, the WEIS data from 1966-1993 exhibits more conflict than cooperation. To give some indication of annual conflict, we plot these data disaggregated by year in Figure 3. Note for the years in common (1990-1993) the WEIS and VRA levels differ, but move in the same direction. We attribute the differences in levels to dissimilar news sources and dissimilar countries between the two data sets. Probably this observed difference between data sets most likely results because WEIS uses the New York Times as its sole source of international relations information. Conflict can easily dominate if the New York Times emphasizes conflict over cooperation in its news reporting or if the New York Times concentrates on a narrower set of (most likely larger more populated) countries. This potential bias could raise concern regarding comparability between datasets. When using data for the United States as actor as it interacts with other nations as shown in Figure 4 we find smaller differences in levels but not direction change for the years in common to both data sets.

\subsubsection{Measuring Trade}

The dyadic trade variable is usually measured in terms of trade volume in millions of current US dollars. Generally dyadic trade is defined as the sum of imports and exports between the actor and target countries. When expressed as a proportion of a country's GDP it attempts to measure the dependence between dyads. Another measure that is constructed is dyadic trade shares (dyadic trade as a proportion of a country's total trade). The empirical findings that use this variable are difficult to interpret. For example, one does not know whether a negative coefficient for a trade share variable arises because of 
a negative relationship between the numerator (dyadic trade) and the dependent variable (conflict) or a positive relationship between the denominator (total trade) and the dependent variable. Indeed the coefficient tends towards zero if both dyadic and total trade are inversely related to conflict. We believe that it is better to adjust for each country's attribute variables separately, rather than to use composite variable like the latter.

\subsubsection{Quantifying Other Country Attributes}

In most empirical studies of trade and conflict, a host of other variables are used as controls. Political scientists often control for a country's power and polity. Economists often control for the level of development. One method of measuring power is to construct a variable based on the COW military capabilities index for each country within the dyad. For example, a common approach is to identify the country with the maximum power and the one with the minimum power within a dyad, i.e., the stronger country and the weaker country. Then the ratio of these two values measures the relative capability of the stronger country over the weaker. Political science theorists predict that the more unbalanced the powers, the less likely they are to engage in conflict. Generally, a categorical variable is also included to indicate whether the dyad includes a major power.

Other variables include regime type. One standard approach to define regime type is obtained by using the Jaggers and Gurr (1995) index. Following Oneal and Russett (1999), to normalize regime types scores to be nonnegative, a constant is added to each score. This variable is also used to test whether democracies are less prone to fight with each other. A joint democracy variable is defined by multiplying the dyad's two regime scores. Higher scores indicate more democratic dyads. Another control variable is 
a political dissimilarity variable based on Henderson (2002) who argues that dyads comprised of similar regime types share peace. This enables us to control whether autocratic states share peace as do joint democracies. Political dissimilarity is defined as the absolute distance between two countries' regime type. In addition, many control for the distance between countries. This is usually done by means of a contiguity categorical dummy variable. This variable measures whether two countries within a dyad share a land border, or share a water border separated by 400 miles or less. Much current research, e.g., Vasquez (1995) argues that contiguous dyads conflict more. Finally, some researchers include World Trade Organization (WTO) membership, given that mutual benefits associate with WTO membership arguably reduces conflict. WTO is coded one if both countries are WTO members, and zero otherwise.

Table 3 presents descriptive statistics for many of these variables over the three time-periods encompassing the events data mentioned above. Consistent with globalization, dyadic trade trends upward. During 1950-2000 average trade rose from \$205 million to \$2.4 billion. We also see two additional secular trends related to globalization. First, democratization is increasing. The average level of joint democracy was measured at 105 between 1948-1978, whereas it was 229 between 1990-2000. With a score of 105 we can say that the average country is slightly autocratic, but with a score of 229 the average country is mid-way democratic. This implies that overall democratic levels throughout the world increased substantially over this time period. Second, membership in GATT and the WTO increased from $34 \%$ in COPDAB (1945-78) to 57\% in VRA (1990-2000). Countries contained in the WEIS data might somewhat overstate 1966-1992 trade because it relies only on countries reported in the New York Times. As 
already mentioned, these countries are probably politically and economically more viable.

\subsection{Statistical Analysis: Testing the Trade-Conflict Theory}

\subsubsection{Single Equation Cross-Sectional Analysis}

Polachek (1978) was the original test of this model. His, as well as most current research address the conflict-trade relationship using a single-equation framework. Typically some measure of bilateral conflict is regressed on a measure of bilateral trade holding country attributes constant. His model was

$$
z_{i j}=\alpha_{0}+\alpha_{1} X_{i j}+\alpha_{2} A_{i}+\alpha_{3} A_{j}+\varepsilon_{i j}
$$

where $z_{i j}$ represents conflict from country $\mathrm{i}$ to country $\mathrm{j}, X_{i j}$ depicts trade from $\mathrm{i}$ to $\mathrm{j}$, and $A_{i}$ and $A_{j}$ reflect attributes of each country. These included population density, percentage GNP originating in industry, highway vehicles, secondary school enrollments, university enrollments, GNP per capita, yearly percentage changes in population, total imports and exports, university enrollments and GNP. These regressions yielded a strong inverse relationship. A $10 \%$ increase in trade was associated with about a $1.5 \%$ decrease in conflict.

Currently numerous other papers provide empirical support for this result. All are single equation, but employ various models ranging from OLS, to GLS, logit and probit as well as Cox regression models. Various measures of conflict and varying sets of independent variables are used. They include Wallenstein (1973), Domke (1988), Oneal et al. (1996), Oneal and Ray (1997) Oneal and Russett (1996, 1999), Sayrs (1990), 
Mansfield (1994), Mansfield, Pevehouse and Bearce (1999), Mansfield and Pevehouse (2000), Crescenzi (2000), Anderton and Carter (2001), Gartzke and Li (2001), Bearce and Fisher (2002), Beck (2003), Gelpi and Grieco (2003), Hegre (2003), McDonald (2004), Bearce and Omori (2005) and Martin, Mayer and Thoenig (2005). On the other hand, only a limited number of articles do not lend support to this specification. They include Barbieri (1996, 2002), Barbieri and Levy (1999), and Keshk, Pollins and Reuveny (2004).

With the exception of Polachek (1980) and Arad and Hirsch $(1981,1983)$ this model largely went unexplored until Pollins' (1989a, 1989b) important articles examining the opposite, namely whether trade is affected by conflict. He estimates the following model:

$$
\ln M_{i j t}=\ln \beta_{0}+\beta_{1} \ln D_{i j t}+\beta_{2} \ln D_{i j t-1}+\beta_{3} \ln P_{i j t}+\beta_{4} \ln P_{i t}+\beta_{5} \ln Y_{i t}+\beta_{5} u_{i j t}
$$

which denotes imports as a function of current and lagged diplomatic cooperation (D), bilateral and world import prices $(\mathrm{P})$, as well as aggregate importer economic activity (Y). For each nation studied, diplomatic cooperation strongly enhances trade. From this, Pollins concludes that "nations adjust trade ties to satisfy security as well as economic welfare goals and that a formal political economy of trade should reflect this fact [(1989b, p.737)]." Of course, this is consistent with the conflict-trade model because the model predicts that trading nations engage in less conflict (more cooperation) because conflict leads to the diminution of trade. Traders thus cooperate in order to protect trade gains. As such, the conflict-trade relationship is simultaneous: conflict reduces trade, and at the same time trade reduces conflict. The problem is that single equation models do not 
distinguish whether both causal relationships hold. One method used to assess this dual causality has been to employ simultaneous equations techniques.

\subsubsection{Cross-Sectional Causality: The Trade-Conflict Relationship With Trade Treated}

\section{Endogenously}

Does trade reduce conflict, does conflict reduce trade, or are both occurring simultaneously? To address this problem a number of studies examine the conflict-trade relationship using a simultaneous equations approach. The first was Polachek (1980) who used a simple two-stage least squares approach to estimate (12). Here the inverse trade conflict-elasticity more than doubled from about 0.15 to 0.35 . Thus a $10 \%$ increase in trade was predicted to decrease conflict by 3.5\%. Later Polachek (1992) utilized threestage least-squares to estimate both equations simultaneously. In one equation, he assumed that conflict affects trade, while in the other he assumed trade affects conflict. However, the approach is limited because of the inherent difficulty in choosing exogenous variables to identify each equation. Essentially, Polachek used defense expenditures to identify conflict and cooperation, and development-type variables such as highway vehicles per capita, secondary school enrollments and electrical production to identify trade. Here he found that a $10 \%$ increase in trade led to a $39 \%$ decrease in conflict, but that a $10 \%$ increase in conflict had insignificant effects on trade. But he did not perform any robustness checks. Later, the issue of simultaneity was again addressed by Reuveny (2001) and Reuveny and Kang (2003). Reuveny and Kang (2003) fit equations separately for ten dyads. They find conflict and cooperation to be a significant determinant of trade and trade to be a significant determinant of conflict and cooperation. However, the signs of the effects varied by dyad. Here too, the strength of the particular 
relationships depends crucially on exogenous variables. As is often the case, there is little theory determining which exogenous variables are most appropriate. For this reason it is also useful to analyze causality in a time-series rather than a cross-sectional framework.

\subsubsection{Time-Series Analysis ${ }^{9}$}

Time-series data are important for two reasons. First such data can establish whether the inverse conflict-trade relationship obtained in the cross-sectional is valid over longer time periods. Second, time-series data can disentangle causality. If changes in trade levels are associated with corresponding changes in political behavior, or vice versa, then one can establish causality based on leads and lags in the time series data.

\subsubsection{A Case Study: U.S./Warsaw Pact Interactions}

To illustrate, Gasiorowski and Polachek (1982) chose US/Warsaw pact countries between 1967 and 1979 as a case study. ${ }^{10}$ These countries and the time period are important because of the volatility in US-Soviet relations during this timeframe. Recall the easing of US-Soviet hostilities in the big détente period of the late sixties and early seventies, and the abrupt shift that began to take place in the mid-1970s.

A time series plots of US-Warsaw Pact trade and conflict from 1967 through 1978 are given the Figure 5. The trade measures, consisting of the sum of imports and exports, are given in real quarterly dollars. The conflict measures are intensity-weighted sums of conflictive events, aggregated quarterly from the COPDAB data. (Relative conflict measures are not needed in time series analysis because the selectivity issues occur in each nation's reporting, but not in one nation's reporting over time.) The trends are in 
accord with prediction. Conflict declines as trade rises in the 1971-1972 period, then levels off until late 1975, as trade remains fairly constant. Both conflict measures show a fairly strong inverse correlation with trade before 1976. This is particularly apparent for Warsaw Pact conflict directed at the United States, which is substantially higher than United States conflict directed at the Pact before mid-1968. These inverse relationships support the contention that greater levels of trade are associated with lower levels of conflict.

The inverse trade/conflict relationship becomes more apparent when the trade and conflict data are plotted directly independent of time-period (Figure 6). Warsaw Pact conflict directed at the United States is given on the vertical axis and US-Warsaw pact trade is on the horizontal axis. The solid lines are linear and hyperbolic fits of the 19671975 data. The inverse relationship between conflict and trade becomes clear in this figure. In addition, it is evident that the relationship is nonlinear, probably hyperbolic.

\subsubsection{Time-Series Causality}

Time-series data enable one to compute Granger type causality tests. To do this, simply ascertain whether trade in one time period affects future conflict, and vice versa. Put simply, increases in explanatory power induced by lagged trade values in a regression of conflict as a function of trade indicates causality running from trade to conflict. With $\mathrm{T}$ representing trade and $\mathrm{Z}$ representing conflict, there is Granger causality if past values of $T$ affect present values of $Z$. The Granger method thus involves a test of the joint hypothesis that $\mathrm{c}_{-\mathrm{i}}=0$ for $\mathrm{i}=1$ to $\mathrm{j}$, where $\mathrm{c}_{-\mathrm{i}}$ is the coefficient of $\mathrm{T}$ lagged $\mathrm{i}$ periods in the following equation: 


$$
Z=c_{0}+a t+b t+\left(c_{-1} T_{-1}+\ldots+c_{-j} T_{-j}\right)+\left(d_{-1} Z_{-1}+\ldots+d_{-j} Z_{-j}\right)
$$

where $\mathrm{c}_{0}$ is the constant term, $\mathrm{t}$ is the time trend, $\mathrm{T}$ and $\mathrm{Z}$ are the lagged values of $\mathrm{T}$ and $\mathrm{Z}$, and $\mathrm{c}$ and $\mathrm{d}$ are coefficients. The null hypothesis that $\mathrm{c}_{-\mathrm{i}}=0$ for $\mathrm{i}=1$ to $\mathrm{j}$ implies that the past values of trade do not predict (and hence "cause") current conflict. This hypothesis can be tested with Fischer's F-Test.

Rejection of this hypothesis implies that some past values of $\mathrm{T}$ significantly affect present Z. Thus, the condition for Granger causality to hold is to reject the null hypothesis. By the same token one can also test the reverse, which is whether past conflict "causes" current trade by re-specifying the above equation as follows:

$$
T=T_{0}+a^{\prime} t+b^{\prime} t+\left(c_{-1}^{\prime} T_{-1}+\ldots+c_{-j}^{\prime} T_{-j}\right)+\left(d_{-1}^{\prime} Z_{-1}+\ldots+d_{-j}^{\prime} Z_{-j}\right) .
$$

In this case, rejection of the null hypothesis that $d_{-i}^{\prime}=0$ for $\mathrm{i}=1$ to $\mathrm{j}$ implies that past conflict affects current trade.

Probability values for Granger F-tests of the null hypotheses that trade does not cause conflict and that conflict does not cause trade for this dyadic relationship during the 1967-1978 time period are consistent with the hypothesis that trade affects conflict. Furthermore, there seems to exist complex lagged structures in the relationship. These results can be viewed as strengthening cross-sectional finding. Specifically, one can improve on the ability of contemporaneous trade to predict conflict by incorporating lagged trade values. Thus, the underlying relationship between trade and conflict is not strictly contemporaneous, but corresponds to a distributed lagged framework. Further work on the appropriate lagged structure is obviously necessary. Research by Reuveny and Kang (1996) extends this work by examining Granger causality for sixteen dyads. 
Using COPDAB and WEIS quarterly data from 1960 to the early 1990s to measure conflict and IMF trade data, they show that causality generally runs in both directions. However, the strength of causality differs by the particular dyad. Thus, examining particular bilateral relationships might lead one to ponder whether the conflict-trade relationship is dyad specific. If so, it is likely that dyad-specific effects influence the conflict-trade relationship.

\subsubsection{Fixed Effects}

The usual procedure to get at the above dyad-specific type heterogeneity is to respecify the empirical model by adding a dyad-specific constant. In the linear form

$$
N C O N F_{i j t}=x_{i j t} \beta+A_{i t} \gamma_{i}+A_{j t} \gamma_{j}+\alpha_{i j}+\varepsilon_{i j t}
$$

where $\beta$ is the common effect of trade, $\alpha_{i j}$ the unobservable dyad-specific effects, and $\gamma$ the effect of individual country attributes. One problem with this usual fixed-effects specification is that it assumes the dyad specific effect acts only through the intercept. However, the fixed effects can operate through the other coefficients, as well. For example, if

$$
N C O N F_{i j t}=x_{i j t} \beta_{i j}+A_{i t} \gamma_{i}+A_{j t} \gamma_{j}+\alpha_{i j}+\varepsilon_{i j t}
$$

one could estimate dyad-specific coefficients for the trade variable $(\beta) .{ }^{11}$ An alternative is to run regressions for each dyad separately, especially since all coefficients can vary by dyad. Given the large number of possible dyads, we present a graph taken from Polachek 
(2002b) of the conflict-trade relation between the U.S. and 115 countries for 1948-1978 in Figure 7. Each line (or curve) represents the best between a linear and hyperbolic bivariate fit (based on $\mathrm{R}^{2}$ ) between U.S. conflict with a specific country and U.S. and each other country. On the vertical axis is an index of U.S. conflict towards each other country. On the horizontal axis is the percent of U.S. trade with each specific target country. Interestingly, not all conflict-trade curves are negatively sloped. While most dyads show an inverse relationship between trade and conflict, a significant number exhibit a positive sign. Do these fixed-effect (fixed-dyad) results contradict the conflicttrade model?

One possibility is that the trade-conflict model is not tested adequately. All empirical results presented relate measures of conflict to levels of trade. However, the theory deals with trade gains, not trade levels. Trade levels and trade gains are proportional when each country exhibits similar import demand and export supply curves. However, it is not clear one can safely assume import demand and export supply curves are so similar, particularly across heterogeneous countries. Basing all empirical work on this crucial assumption may be erroneous. Of course, this assumption does not negate the theory, just the empirical implementation. Thus, one can modify the empirical implementation to rid the analysis of this assumption. If one does this, the results strengthen dramatically.

\subsubsection{The Trade Conflict Relationship Augmented By Bilateral Import Demand} Elasticities $^{12}$ 
Recall that the conflict-trade model hypothesizes that the welfare gains from trade induce bilateral cooperation and diminish conflict. The above empirical tests use trade to proxy welfare gains. However, as just indicated above, trade is an imperfect measure of welfare gains. Welfare gains are the sum of each trading partner's respective producer and consumer surpluses. Indeed, producer and consumer surplus are proportional to trade, but they are also inversely related to import and export demand and supply price elasticities. The more inelastic these import demand and export supply functions, the greater the trade gains, holding trade levels constant. Failing to utilize demand and supply elasticities implies an omitted variable bias. Even the sign of this bias is impossible to determine since one cannot predict the correlation between trade level and trade elasticity. Neglecting these elasticities can bias the statistical work used in current tests of the trade conflict hypothesis, thus making them unreliable. For this reason, incorporating elasticities to get at trade gains might shed light on some of the perverse results from the above fixed-effect analysis.

To incorporate these gains from trade measures, Polachek and McDonald (1992) augment the basic conflict-trade equation (12) by incorporating import demand elasticities to get at trade gains. Letting $g_{i j}$ represent trade gains arising from actor i's trade with $\mathrm{j}$, they rewrite the trade-conflict equation as

$$
z_{i j}=\alpha_{0}+\alpha_{1} g_{i j}+\alpha_{2} A_{i}+\alpha_{3} A_{j}+\varepsilon_{i j} .
$$

Here,

$$
g_{i j}=\int_{0}^{i m p o r t s} p_{m}\left(m_{i j}\right) d m_{i j}+\int_{0}^{\text {exp orts }} p_{x}\left(x_{i j}\right) d x_{i j} .
$$


Solving the integral implies that gains from trade are proportional to trade levels but inversely related to trade elasticities. Thus, the gains from trade are proportional to the sum of imports and exports, weighted by the inverse of their respective import demand and export supply elasticities, as indicated below:

$$
g_{i j}=m_{i j} / \varepsilon_{m_{i j}}+x_{i j} / \varepsilon_{x_{i j}}
$$

Relating trade and price elasticity to gains from trade means that incorporating these data in the conflict-trade model implies trade and conflict to be inversely related, as previously observed. But in addition, conflict is positively related to import demand (and export supply) price elasticities. Thus one should incorporate these elasticities to test the conflict-trade hypothesis.

Ideally one would desire commodity-specific elasticities to test whether trade in specific commodities affects international relations. However, to date, no comprehensive commodity-specific bilateral elasticities are available. ${ }^{13}$ Nor are there any export supply price elasticities readily available, even on the aggregate level. So Polachek and McDonald (1992) concentrate on augmenting the conflict-trade model with demand elasticities computed by Marquez $(1988,1990)$ and Hooper et al. (1998) obtained from the existing empirical international trade literature. Adopting Goldstein and Kahn's (1985) imperfect substitute model, Marquez $(1988,1990)$ estimates income and price elasticities for bilateral import demand equations by utilizing a world trade model he developed with data from 1970 to 1984 . To incorporate these elasticities, the empirical specification is further modified as follows:

$$
z_{i j}=\alpha_{0}+\alpha_{1} m_{i j}+\alpha_{2} x_{i j}+\alpha_{3} \varepsilon_{m_{i j}}+\alpha_{4} \varepsilon_{x_{i j}}+\alpha_{5} A_{i}+\alpha_{6} T_{j}+\varepsilon_{i j},
$$


where $\mathrm{m}_{\mathrm{ij}}$ and $\mathrm{x}_{\mathrm{ij}}$ represent dyadic imports and exports, $\varepsilon_{m_{i j}}$ and $\varepsilon_{x_{i j}}$ represent import and export demand and supply elasticities and A and T depict actor and target attributes. Regression results for the Marquez elasticity augmented conflict trade model using country trade and attribute data for 1973 to maintain time period compatibility with the 1970-1984 Marquez elasticities are given in Table 4. They show conflict to be inversely related to trade, but interestingly the magnitude is far stronger than in past estimates. A doubling of imports leads to a 50\% conflict reduction. Similarly, a doubling of exports leads to a $30 \%$ decline in conflict. (Recall previous estimates yield about a $15 \%$ reduction in conflict.) To enhance the gains from trade argument, the difference in actor-target gross national product (GNP) is used as an exogenous proxy for differences in factor endowment. If actor and target GNP differences (GNPDIF) imply differences in actor-target factor endowment, then larger GNPDIF should raise the gains from trade and diminish conflict. Here the regression result (-.56) is also consistent with the tradeconflict hypothesis.

The result for import demand elasticity is most important. Here, as mentioned earlier, theory predicts a positive relation between the import demand elasticity and conflict, and indeed this positive relation is observed. The 37.62 coefficient implies that a 10 percent more inelastic demand is associated with a $4.7 \%$ lower level of conflict. What is significant is that incorporating import demand elasticities not only yields the predicted sign, but strengthens previous finding regarding trade's effects on conflict, as well. But the analysis can be extended even further.

Albeit for only 14 of the largest OECD countries, Polachek and McDonald (1992) exploit the International Monetary Fund 's (IMF) World Trade Model (WTM) to devise 
import and export price elasticities for three important commodity groups: manufactures, agricultural goods, and raw materials [see Haas and Turner (1988) for a description of the model]. The WTM emphasizes the demand for a country's exports as the weighted sum of its trading partners' imports. Import demand functions depend on domestic activity and relative prices. Export supply is determined by the foreign market size, relative export prices, and capacity utilization. These equations are estimated for 1962-1983. Bilateral trade elasticities can be obtained using trade share matrix methodology outlined by Armington (1969). According to Armington, country i's demand elasticity is proportional to a share-weighted sum of a country's elasticity of substitution for a commodity (between any pair of countries) and the partial elasticity of demand buyers in country i have for the commodity in general, irrespective of the source of supply. Specifically,

$$
\mathrm{N}_{\mathrm{ij}}=\left(1-\mathrm{S}_{\mathrm{ij}}\right) \mathrm{e}_{\mathrm{i}}+\mathrm{S}_{\mathrm{ij}} \mathrm{n}_{\mathrm{i}}
$$

where, $N_{i j}=$ the ith country buyers' partial elasticity of demand for the commodity produced by the $j$ th country, $S_{i j}=$ the share of the $j$ th country's expenditures for the commodity in the ith country's total expenditures on the commodity, $\mathrm{e}_{\mathrm{i}}=$ the elasticity of substitution in the ith market between the commodity and any pair of countries (including the ith), and $n_{i}=$ the partial elasticity of demand country i's buyers have for the commodity irrespective of the source of supply. When $i \neq j, n_{i j}$ is the ith country's import demand elasticity from $\mathrm{j}$. Using the above equation, demand elasticities obtained from the WTM can be converted into bilateral elasticities. The shares $\mathrm{s}_{\mathrm{ij}}$ are calculated from a square trade matrix for each of the three commodities (again, manufactures, agricultural products, and raw materials) using detailed OECD trade flow information. 
The elasticity of substitution can be obtained by using related estimates available from Marquez (1988).

Using this methodology and concentrating on manufactures shows the tradeconflict relationship holds. All the empirical work finds the signs are consistent with expectations. In addition, this research has shown that the export and the import elasticities continue to be important determinants of net conflict. Yet, under this specification exports appear to be more important to reducing conflict than imports. The results for the trade-conflict relationship using bilateral elasticities for raw materials show less variation in these elasticities than for manufactures. As before, all signs are consistent with the trade-conflict hypothesis. A doubling of exports leads to a $43 \%$ decrease in conflict. GDP differences are associated with less conflict and the Armington coefficients are consistent with less conflict when bilateral import demand curves are more inelastic.

\section{An Application -- The Democratic Peace: Why Democracies Don't Fight Each Other ${ }^{14}$}

\subsection{The Issue}

Ever since 1979 when Rummel (1979b) cited Babst's relatively obscure article analyzing Wright's (1942) war data that "no wars have been fought between independent nations with elective governments" interest intensified to test the proposition that democracies do not fight each other. Earlier work such as by Wright (1942), Gregg and Banks (1965), Haas (1965), Russett and Monsen (1975), Small and Singer (1976) and even Rummel (1968) himself, considered democracies to be equally war prone as other states. Even research scholars pursuing their work immediately after Rummel's claim 
were skeptical. For example, based on data in the 1960s and 1970s, Weede (1984) demonstrates that democracy and war "are not consistently and significantly correlated with each other." According to him, only in the late seventies - "a period that seems rather exceptional" - did democracies succeed in avoiding involvement in wars. Domke (1988) using Gurr's Polity I data set "failed to find any consistent association between the degree of democracy and the likelihood of war" [Bremer (1992a, p.316)]. Similarly Dixon (1989) failed to find an association between democracy and the frequency of war over the time span 1816-1971. Additionally, though hotly contested by Rummel (1987), Vincent (1987) presents regression equations claiming "virtually no relation between dyadic freedom and dyadic conflict."

In contrast to this skepticism, there is other evidence providing ample reason to suspect that democracies in fact do deter conflict. Wright (1942) followed later by Doyle (1986) argue based on political theory dating back to Kant (1795) that "democracies must favor development of peaceful modes of international settlement because they are dependent upon law." In addition, Doyle (1986) cites empirical evidence dating back to Streit (1938) that democracies deter conflict. In espousing the need for a union of nations with fifteen democracies as the nucleus to foster peace, Streit states "No two of the fifteen have fought each other since the Belgian-Dutch war of 1830 . There is no parallel in politics to this achievement of democracy in maintaining peace so long among so many powerful, independent and often rival peoples, burdened with hatreds and prejudices left behind by all the previous fighting among them before they achieved democracy" [Streit (1940, pp.:66-7)]. Further Watkins (1942) found that democracies cooperated overwhelmingly more than non-democracies in the League of Nations. As 
evidence, he finds that "whereas 23 (55 per cent) of the non-democracies have a poor record of cooperation in international organization, only one ( 5 per cent) of the democracies can be classed with them."

In a well cited paper, Chan (1984) rectified these paradoxical differences regarding whether or not democracies deter conflict. His solution to the problem was mostly methodological: Monadic studies using single countries as the unit of observation fail to support the contention that democracies rarely fight. On the other hand, strong support emerges using dyads as units of observations. Indeed using the Small and Singer (1982) Correlates of War (COW) data, Chan finds overwhelming support that "the more libertarian two states [are] the less the mutual [emphasis mine] violence" [Chan (1984, p. :620)] while he finds little support that "the more libertarian a state, the less its foreign violence" [Chan (1984, p. 620)]. Chan's study thus served as an impetus for a number of dyadic-based tests of the hypothesis. These, in turn, have led to a number of further studies seeking reasons why the relationship holds. These studies include: Maoz and Abdelali (1989), Levy (1989), Morgan and Campbell (1991), Morgan and Schwebach (1992), Siverson and Emmons (1991), Ray (1993), Ember et al. (1992), Bremer (1992a, 1993), Russett and Antholis (1992), Mintz and Giva (1993), Maoz and Russett (1993),, Farber and Gowa (1997), Kegley and Hermann (1996), Eyerman and Hart (1996), Thompson and Tucker (1997), Gartzke (1998), Dixon (1998), Mousseau and Shi (1999), Cederman et al. (2001), Doyle (2005), Slantchev et al. (2005), and Kinsella (2005). Noteworthy among these studies is the consistency of the findings; so much so that Levy (1989) calls the "democracies rarely fight" phenomena a "law," and Bremer (1992b) indicates that an "ISA Atlanta Panel composed of Bruce Bueno de Mesquita, Steve Chan, 
T. Clifton Morgan, Harvey Starr, Eric Weede and ... [himself] ... gave unanimous support to the proposition" [Bremer (1992b, p.1)]. Nevertheless these papers reveal that the strength of the relationship depends on how wars are defined (i.e., whether one uses Correlates of War or MIDS data), whether one is talking about originating a war or merely joining a war, whether one is talking of "covert" activity, and finally on which time period one is considering.

Given these latter qualifications, it is essential to determine how the relationship holds up both with respect to conflict less severe than militarized disputes as well as with respect to cooperative behavior. Neither COW, MIDS nor alliance data, used in virtually all current studies, can answer this question fully because they include only specific and narrow types of conflict and cooperation. In addition, with war data the direction of conflict, i.e., who is the aggressor and who is the defender, is often difficult to discern. While not without shortcomings, events data contain a wide range of dyadic interactions which are more suitable for testing the impact of democracy. These data include both the severity of conflict and the extent of cooperation, as well as the directionality of each. In addition, because of the relatively large variation in the degree of conflict and cooperation across dyads, one can look not only at democracies and non-democracies, but also one can separate out non-democracies into cases where only the actor is a democracy, cases where only the target is a democracy, and cases where neither actor nor target are democracies. For this reason, it is useful to review more broadly the "do democracies 'fight' each other" question using events data.

Once it is established that these data show democracies to exhibit less conflict with each other, we analyze the deeper question of why democracies fight less, a question 
about which there is now also a burgeoning literature. The innovation here by Polachek (1997) was to show that democracies are richer and have more trade. To protect this wealth, democracies conflict somewhat less and cooperate considerably more. Nondemocracies have less to protect and as a consequence conflict more and cooperate less. This is the theme we emphasized earlier in the gains-from-trade argument.

\subsection{The Evidence}

\subsubsection{Measuring Democracy: Ted Gurr Data}

The Gurr data codes countries' structural and institutional characteristics as they change over time. Central to the data are measures of democracy, autocracy, and power concentration. The consensus measure of democracy is the "institutionalized democracy" variable which is an amalgamation of three independent elements: (1) citizens' abilities to express their preferences to country leaders, (2) checks and balances on the executive branch, and (3) the degree to which citizen civil liberties are protected. Gurr provides a composite scale, which ranges in value from 0 to 10 , with 10 denoting the most democratic country.

Most studies use a dichotomous version of this variable, but it seems to make sense that rather than throw away information on fine gradations, one should treat the democracy variable as continuous. Yet sometimes in order to anchor one's results to past studies, we must also present outcomes with a dichotomous democracy specification. We recommend the use of two dichotomous specifications: one being more stringent with a country being classified as a democracy if it achieves a Gurr index of 7 or higher; and a less stringent measure allowing for a Gurr index of 5 or higher. Note that Bremer (1992a) uses the less stringent definition. Farber and Gowa (1997) define a democracy as 6 or 
higher. Generally, there are only small differences in results whether democracy is treated continuously or dichotomously. Similarly, virtually the same results emerge for both dichotomous specifications of democracy.

As for the empirical findings, regression results uphold the finding that democratic dyads have 1.51 units less conflict on the COBDAB scale than nondemocratic dyads, and that mixed dyads (one democracy and one non-democracy) have between 0.85 and 2.58 units more conflict depending on whether the pair contains a nondemocratic actor and democratic target (2.58) or a democratic actor and non-democratic target (the comparison group). One should note too that these results hold up even if the U.S. as a target is eliminated. This implies that U.S. vented conflict is not driving the results, as one might have expected during the 1960s.

\subsection{Conclusions From the Trade-Conflict Model Regarding the Democratic Peace}

Two theories are given to explain why democracies rarely fight each other. The first theory is billed as cultural-normative, and the second as structural. In reality both are related because in part structural determinants are possibly culturally induced. Culturalnormative theories are based on Kant (1795), Wright (1942), and Doyle (1986), and advanced by Russett (1989) and others. They claim that adjudication and bargaining are so embedded within democratic societal norms that democracies are able to solve disputes peacefully, especially with other democracies (though the logic is a bit murky why democracies don't do better against non-democracies, as well). Structural theories, espoused by Morgan and Campbell (1991), and based on Rummel (1979a), Hagan (1987), Domke (1988), and Bueno de Mesquita and Lalman (1992), argue that there are so many checks and balances in the democratic decision process that making the decision 
to fight is difficult and not taken lightly, though one might have difficulty using this logic to explain why democratic actors don't fare much better against non-democratic targets than non-democracies. Non-democracies such as dictatorships need less justification to go to war. Zinnes (2004) uses propositional calculus to provide an explanation based on normative as well as these structural factors.

Distinguishing these two theories requires isolating identifiable structural characteristics defining decision constraints which explain why democracies rarely fight each other. Failing to find such characteristics would lead one to conclude in favor of innate cultural/normative characteristics of democracies. In this vain Morgan and Campbell (1991) favor the structural characteristics interpretation by showing that at least for major powers "higher levels of decisional constraints lead to a lower probability that conflict will escalate to war." . However, being bothered by "weak statistical significance" [(1991, p. 206)] they temper their conclusion indicating the possible validity of cultural norms as well. In contrast, Maoz and Russett (1992, 1993), while arguing that "both the normative and structural models are supported by the data [(1993, p. 624)]," conclude in favor of cultural-normative theories because democracies seem to have an independent effect in their statistical analysis even after controlling for other variables. They use GDP per capita relative to the U.S. (wealth), percent GDP change (growth), contiguity, COW alliance data, and Gurr political stability data.

Finding that democracy significantly deters conflict in a regression does not rule out spurious effects. In fact, finding democracy to be significant might merely indicate that researchers haven't as yet found the appropriate determinants of conflict. In this case the democracy variable serves as a proxy for underlying factors not accounted for in the 
data. It is in this vain that Polachek (1997) tries to build on past theories of how international trade is related to conflict to forge a possible explanation for why "democracies rarely fight each other." His explanation differs from Starr (1992) who presents a game theoretic model of dove and non-dove nations, and from Lake (1992) who adopts a public choice type model in which the pacifism of democracies emerges among non-imperialist nations interested in maintaining security.

Before turning to the conflict among democracies question, we anchor this issue to the past results relating trade and conflict: To be applicable, one would have to show that democratic dyads exhibit greater trade (or greater gains from trade) than nondemocratic dyads, and that as a consequence the greater trade contributes to greater cooperation and less conflict. Democracies cooperate more and conflict less to protect greater welfare levels arising from trade gains. By cooperating rather than fighting, trade is protected and individual welfare is enhanced by per capita increases in GNP attributable in part to these gains from trade.

To test the validity of this scenario one must show first that democratic dyads in fact trade more, and show second that this greater trade is related to lower amounts of conflict. In fact, imports average $\$ 341$ billion and exports $\$ 314.13$ billion for democratic dyads, and only $\$ 14.2$ to $\$ 15.6$ billion for non-democratic dyads. Consistent with the above hypothesis, democratic dyads exhibit far greater levels of trade. The mixed dyads have trade levels in between. This might be somewhat puzzling to the above hypothesis that trade is directly related to conflict since as one would expect conflict to be in between the purely democratic and purely non-democratic dyads. However, as indicated, trade may be an inappropriate measure of gains from trade. These results are upheld 
when looking at correlations between democracy and trade. Democratic dyads engage in more trade: The correlation between trade and the Gurr democracy index (DEMOC) is strongly positive varying between 0.21 and 0.36 depending on the trade index. This positive correlation is roughly the same magnitude when using the dichotomous democracy index: 0.17 to 0.31 for the stringent definition of democracy and between 0.23 and 0.32 for the weaker democracy definition. Non-democratic dyads have lower dollar trade levels. The correlation here is -0.14 . However, GNP weighted trade is not significantly lower for non-democracy pairs. The correlation is between -.01 and .02 , and not statistically different from zero. For the mixed democracy/non-democracy dyads, trade is significantly lower for both dollar and GNP-weighted trade measures. Thus these correlations are consistent with trade being the underlying reason democracies fight less with each other: Nation pairs with more trade exhibit less conflict, and democracy-pairs exhibit more trade. Thus it is possible that the greater trade between democracies is the underlying cause for less conflict among democratic dyads. Similarly the lower relative trade associated with mixed democracy/non-democracy pairs might be responsible for the greater conflict between these mixed country pairs.

Regression analysis yields almost the same story. Modeling conflict as a function of the continuous democracy score yields that the higher the product of both country's Gurr democracy scores, the more democratic the dyad and the lower the level of net conflict (-.028). Also consistent with the above is an inverse relationship between conflict and trade since the coefficient for trade is generally found to be significantly negative. Thus it appears that trade deters conflict as reported in previous research, and more democratic dyads exhibit less conflict. One might argue that the negative democracy 
coefficient is possibly spurious if democracy proxies some other underlying factor. For example, if democracies have greater levels of trade which in turn decrease conflict, then omitting trade from the analysis could cause an omitted variable bias. One way to test for this is to consider whether conflict is jointly determined by democracy as well as trade. If rather than democracy per se decreasing conflict, one finds that higher levels of trade cause lower levels of conflict then the democracy coefficient will become insignificant once one includes trade in the regression model. This approach has been used and it is found that the democracy coefficient decreases in magnitude when trade is introduced linearly, and decreases further to a statistically insignificant level when trade is introduced in a quadratic form. Thus introducing trade explains away democracy's impact. It is important to note that the trade coefficient remains exactly the same magnitude and significance. This is consistent with democracy being a proxy for trade rather than trade for democracy. This result is invariant to the use of the categorical democracy variables rather than democracy measured continuously. As before, democratic-democratic dyads exhibit less conflict. Furthermore, adding trade reduces the magnitude and statistical significance of the democracy coefficient. Here too, it is important to note that the trade coefficient remains exactly the same. Thus again democracy is a proxy for trade rather than the reverse.

Obviously it is possible that trade too might not be an independent factor. Perhaps larger more developed countries are the ones with greater trade. To test this possibility, introducing GNP and population for both the actor and target leaves the trade coefficient the same. Introducing the dyadic democracy variables raises the dyadic democracy coefficient but leaves unaltered its statistical insignificance. Thus even when accounting 
explicitly for country size (both in terms of the economy and population) trade decreases dyadic conflict, but democracy pairs no longer exhibit lower levels of conflict. In fact, it could argue that once controlling for trade and country attributes democracies seem to exhibit greater conflict.

Yet, non-democracies have 2.6 units more conflict when dealing with democracies than non-democracies. Trade per se explains little of this difference in conflict. However, trade and wealth differences when taken together explain $54 \%$ of this difference and adding GNP nonlinearly with trade virtually explains the whole difference. Going further, by accounting for the greater conflict levels democracies exhibit towards non-democracies, the research shows that non-democracies actually exhibit less conflict towards democracies than non-democracies. ${ }^{15}$ In conclusion, these results together imply that all levels of inter-dyadic conflict can be explained. In short, at least using events data sets, democracy is not the relevant variable in explaining conflict. Dyadic differences in conflict are essentially fully accounted for by trade and wealth differences across nations. Encouraging free trade which through "gains from trade" tends to increase each nation's wealth appears to be the key to decreasing conflict and increasing cooperation.

Not all political scientists agree that trade represents the underlying foundation of the democratic peace. For example, Russett and Oneal (2001) claim that the " $20^{\text {th }}$ century has been marked by a hopeful evolution of a zone of peace" because nations are better able to triangulate peace based on democracy, trade, and the increased role of international governmental and nongovernmental organizations. While it is possible democracy and trade can instigate peace, it is not clear they act independently. Because democracies tend to be more open and to engage in more trade than autocracies, greater 
trade may induce their pacific role. The theories that advocate the view that democracies are more peace prone largely fail to explain why liberal states achieve peace solely with other democracies. ${ }^{16}$ For this reason a number of articles are skeptical of democracy's independent role. Rosato (2003) argues that whereas there is peace among democracies, it is not a result of their democratic nature. He claims democracies do not trust one another more, elected leaders are not "peace loving" and democracies are not particularly slow to mobilize. Further he claims that democracies are just as prone as other countries to avoid revealing private information about its level of resolve regarding disputes. Mousseau (2005) argues that the democratic peace is contingent on levels of development. He finds that democracies appear to be a significant war deterrent only in the richest $45 \%$ of the dyads. Based on theoretical game theory models, Bueno de Mesquita, et al. (2004), argue one cannot determine a priori the pacific effects of democracies. On the one hand, the bargaining model predicts democracies draw out disputes so that diplomats have time to find non-war solutions. On the other hand, the way democracies select the disputes to participate in make disputes between democracies shorter. Zeng (2004) uses a two-level game approach to show how the democratic peace does not hold with regard to U.S. trade wars. It is possible that trade competitiveness between democratic regimes creates an impetus to use threats, thereby increasing the likelihood of a trade war.

\section{Extensions of the Conflict-Trade Model}

A number of factors influence gains from trade. These include type of trade, country size, market competition, country contiguity, tariffs, foreign aid, and the number of countries in the international system. Just recently, a number of authors have begun to 
examine some of these aspects of the conflict-trade relationship. In this section, we briefly touch on these issues.

\subsection{Commodity-Specific Trade}

A number of papers examine how the conflict-trade relation differs depending on the commodities traded. Polachek (1980) finds that oil importers are more cooperative toward oil exporters. Polachek and McDonald (1992) show that conflict decreases when OECD nations trade manufactured goods and raw materials. This inverse relation is enhanced the more price inelastic are these imports. Using 1963-1980 trade data for several OECD countries in five commodity categories (agriculture-fishery, energy, oresminerals, manufactured goods, and miscellaneous consumer goods), Reuveny and Kang $(1996,1998)$ find that the strength of the conflict-trade relation depends on the specific commodities. A rise in trade generates cooperation in 15 cases they examine and conflict in nine. They find a rise in agriculture-fishery and energy trade generates cooperation, whereas the effect for ores-minerals, manufactured goods, and miscellaneous consumer goods is mixed. As Reuveny and Kang recommend, more research is warranted in this area.

\subsection{Foreign Direct Investment}

Not only is trade increasing, but the amount of capital flows is as well. As global integration has expanded, countries have moved into a more complicated interdependent network. Foreign direct investment's annual growth rate exceeded the growth of international trade over the past decade and broke through the trillion U.S. dollar level in 2000. This contrasts with the period of the 1960s and 1970s when 
countries were concerned with the possibility that their sovereignty would be reduced by multinational foreign direct investment. The focus now is on the positive effects of FDI and other types of capital flows on the home and host countries' economies. This change in attitude was complemented by the adoption of favorable policies by many countries to attract FDI. These developments raise the possibility that the role of direct investment in determining interstate relationships has increased in importance.

Research on the impact of foreign investments by multinational corporations $(\mathrm{MNC})$ on the international system predates the recent increase in globalization. The more conventional literature [Vernon (1971), Gilpin (1975) and Nye (1974)] takes the view that multinational corporations $(\mathrm{MNC})$ are tied to their home countries and that nation states are still the principal actors in the international system. However, if multinational firms are essentially national firms competing with one another around the globe, as Gilpin (2001) points out, then one would expect some correlation between the direct investments of multinationals and the foreign policy of their home countries.

There is now a literature examining the determinants of FDI. ${ }^{17}$ But FDI's effects on international relations is still at its infancy. Thompson (2003) argues that direct investment draws countries closer to each other thereby decreasing the probability of deadly conflicts. In empirical work using post World War II data, he illustrates that reciprocal FDI flows leads to fewer instances of conflict. Using the current political atmosphere he argues that United States, China, and Taiwan are drawn closer together because FDI flows between the countries instigates the necessity to maintain stability. 
Based on information from World War I, Thompson argues that the warring countries had little or no FDI leading to diminished integration. In a sense this latter finding helps explain the paradox that trading nations participated in World War I whereas conflict-trade theory argues that trade should have deterred conflictive activity.

Polachek, Seiglie and Xiang (2005) also examine how FDI affects conflict and cooperation. They invoke a three-stage least squares simultaneous equations model using bilateral FDI flows from 1990-2000 and the VRA data mentioned earlier. One equation models FDI as a function of actor and target cooperation (actually net cooperation defined as the weighted cooperation minus conflict directed from an actor to target nation) and such country attributes as population, school enrollment, telephone mainlines, and gross capital formation -- all of which measure levels of development. The other equation specifies net cooperation as a function of FDI, actor and target GDP, joint democracy and contiguity.

According to their results (Table 5), FDI has a significant positive effect on the net cooperation variable (0.014). For a one million U.S. dollar increase in FDI within a dyad, on average net conflict will be reduced by 0.014 units (i.e., net cooperation will increase by 0.014 units). Translating this to an elasticity measure yields 0.31 meaning that increasing FDI by $1 \%$ yields an increase in cooperation by $0.31 \%$, on average. The coefficient on the net cooperation variable (23.0 in column 2) also confirms that cooperation has a significant positive impact on FDI. This coefficient is consistent with FDI enhancing dyadic relationships. In this case, a one-unit change in net cooperation will increase one FDI by about $\$ 23.0$ million. The elasticity for this 
relationship is 1.036 . Thus a $1 \%$ increase in net cooperation will increase FDI by $1.04 \%$.

\subsection{Country Size}

Alesina and Spolaore (2003) develop a brilliant yet parsimonious model, capable of cogently addressing country size. They define nations as powerful entities whose prime purpose is to ensure well-being for their citizens. Larger countries permit economies of scale, so per citizen costs for public goods, such as defense, diminish; but by becoming large, a nation grows more heterogeneous, making the country more difficult to manage. Bigger populations imply diversity, but diversity complicates how leaders provide public goods because a wide-ranging citizenry often have conflicting interests. The tradeoff between these two, i.e. scale and heterogeneity, determines any particular nation's size. Any factor that alters this tradeoff influences a nation's size. As an illustration, large countries need not trade as much as small countries because their size brings a greater variety of resources and more self-sufficiency. At the same time larger countries possess economies of scale in providing a powerful military. A world environment that encourages free and open trade leads to more trade. At the same time, greater trade implies a lesser need for self-sufficiency, and results in smaller countries [Alesina and Spolaore (2003, Chapter 6)]. In contrast, a more belligerent world with more conflict leads countries to demand a larger military. To accomplish this, nations seek economies of scale to finance defense. As such, countries become relatively large [Alesina and Spolaore (2003, Chapter 7)]. According to Alesina and Spolaore (2003: p. 127) "these two effects are not unrelated once ... [one considers the] connection between conflict and trade." Conflict induces larger countries that trade less, but less 
trade brings about more conflict. On the other hand, smaller countries trade more, but greater trade enhances peace.

\subsection{Multilateral Interactions ${ }^{18}$}

Bilateral trade is not independent of other countries. Feng (1994) relates trade to alliance conflict. He finds that the relationship between trade and alliance conflict depends upon what he calls externality cost. Externality costs implies that conflict with friends of allies is more costly than with friends of foes. As such, post-World War II trade between the United States and an ally (e.g., Britain, Canada, France, West Germany, Italy and Japan) increased in direct proportion to conflict between the United States and Soviet Union. How alliances form and how third parties intervene in ongoing conflicts form a large political science literature [e.g., see Altfield and Bueno de Mesquita (1979); Holsti et al., (1973); Kim (1991); Sabrosky (1980); Singer and Small (1966a; 1966b); Siverson and King (1979, 1980)]. In this vein, Altfield (1984), Morrow (1991), Powell (1991), and Simon and Gartzke (1996) among others base alliances on security gains from joining a coalition. Altfield and Bueno de Mesquita (1979) use an expected-utility model to predict that intervention depends on the utility gained from one or the other party winning. As such intervention is more likely if a third party gains considerable utility from one country winning, instead of another.

One can incorporate multilateral interactions into the conflict-trade framework described above. Going back to a country's objective function (specified in (1)), simply denote all possible targets as $\mathrm{i}=1, \ldots, \mathrm{n}$. In this framework, we now denote actor A's utility function as

$$
\mathrm{U}_{\mathrm{A}}=\mathrm{U}_{\mathrm{A}}\left(\mathrm{C}, \mathrm{Z}_{1}, \mathrm{Z}_{2}, \ldots, \mathrm{Z}_{\mathrm{n}} ; \mathrm{U}_{1}, \mathrm{U}_{2}, \ldots, \mathrm{U}_{\mathrm{n}}\right)
$$


where $i=1, \ldots n$ denotes each of the world's $n$ countries actor $A$ faces. The variable $Z_{i}$ reflects conflict with each country $i$. The variable $U_{i}$ depicts welfare levels of each other country. As before, $\partial \mathrm{U}_{\mathrm{A}} / \partial \mathrm{Z}_{\mathrm{i}}>0$ depicts the welfare gain from conflict with country $\mathrm{i}$. But now, $\partial \mathrm{U}_{\mathrm{A}} / \partial \mathrm{U}_{\mathrm{i}}$ designates how country i's welfare affects the actor. $\partial \mathrm{U}_{\mathrm{A}} / \partial \mathrm{U}_{\mathrm{i}}>0$ implies $i$ is a friend, while $\partial \mathrm{U}_{\mathrm{A}} / \partial \mathrm{U}_{\mathrm{i}}<0$ implies $\mathrm{i}$ is an enemy. As such, an actor's welfare is higher the higher the welfare of a friend, and smaller the higher the welfare of a foe. More generally, for any two nations $i$ and $j \partial U_{i} / \partial U_{j}>0$ implies $i$ and $j$ are friends and $\partial \mathrm{U}_{\mathrm{i}} / \partial \mathrm{U}_{\mathrm{j}}<0$ implies $\mathrm{i}$ and $\mathrm{j}$ are enemies.

Whereas an actor's conflict toward country i can increase actor welfare $\partial \mathrm{U}_{\mathrm{A}} / \partial \mathrm{Z}_{\mathrm{i}} \geq 0$, it most certainly decreases the target's welfare since no country likes to be the recipient of conflict. Thus, $\partial \mathrm{U}_{\mathrm{i}} / \partial \mathrm{Z}_{\mathrm{i}}<0$. Based on these inequalities, one can show that friendship mitigates conflict while rivalry increases conflict. To illustrate, recall that the marginal benefit of conflict $\partial \mathrm{U}_{\mathrm{A}} / \partial \mathrm{Z}_{\mathrm{i}}$ equals $\partial \mathrm{U}_{\mathrm{A}} / \partial \mathrm{U}_{\mathrm{i}} \cdot \partial \mathrm{U}_{\mathrm{i}} / \partial \mathrm{Z}_{\mathrm{i}}$. This term is negative when actor $\mathrm{A}$ and target $\mathrm{i}$ are friends $\left(\partial \mathrm{U}_{\mathrm{A}} / \partial \mathrm{U}_{\mathrm{i}}>0\right.$ and $\left.\partial \mathrm{U}_{\mathrm{i}} / \partial \mathrm{Z}_{\mathrm{i}}<0\right)$. Based on the previous analysis, the marginal benefit curve shifts down implying less conflict between friends (Figure 8). Conversely, the marginal benefit curve shifts up (Figure 9) leading to more conflict when $\mathrm{A}$ and $\mathrm{i}$ are rivals $\left(\partial \mathrm{U}_{\mathrm{A}} / \partial \mathrm{U}_{\mathrm{i}}<0\right.$ and $\left.\partial \mathrm{U}_{\mathrm{i}} / \partial \mathrm{Z}_{\mathrm{i}}<0\right)$. Thus friendships and rivalries affect dyadic relations.

But friendships and rivalries also affect multilateral interactions. Consider three countries: (1) an actor A, (2) a target $\mathrm{i}$, and (3) a country $\mathrm{j}$ that can either be a friend or foe of i. Examine how an actor's conflict with country i changes when its trade with country $j$ rises. Here an actor's conflict with country $i$ declines if country $j$ is a friend of $i$, 
and increases if countries $i$ and $j$ are rivals. Trade with a friend-of-a-friend decreases conflict, while trade with a foe-of-a-friend increases conflict.

To see this, recall that bilateral trade increases cooperation and decreases conflict. Thus an actor's conflict with $\mathrm{j}$ would decrease if its trade with $\mathrm{j}$ increases $\left(\partial \mathrm{Z}_{\mathrm{j}} / \partial \mathrm{x}_{\mathrm{j}}<0\right)$. A lower conflict level with $\mathrm{j}$ raises country $\mathrm{j}$ 's welfare because $\partial \mathrm{U}_{\mathrm{j}} / \partial \mathrm{Z}_{\mathrm{j}}<0$, but in turn a higher welfare for country $j$ raises country $i$ 's welfare when countries $i$ and $j$ are friends. Finally, an increase in country i's welfare raises the actor's welfare, thereby implying that conflict with country i decreases. As such, trade with a friend-of-a-friend decreases conflict. This would be illustrated in Figure 8 by a downward shift in conflict's marginal benefit curve, thereby decreasing conflict. The scenario for a foe-of-a-friend is the opposite.

Trade with an enemy-of-a-friend raises conflict. To see this, follow the same logic as above. An actor's conflict with $\mathrm{j}$ decreases as its trade with $\mathrm{j}$ increases. Thus $\partial \mathrm{Z}_{\mathrm{j}} / \partial \mathrm{x}_{\mathrm{j}}<0$. Decreased conflict with $\mathrm{j}$ raises country j's welfare because $\partial \mathrm{U}_{\mathrm{j}} / \partial \mathrm{Z}_{\mathrm{j}}<0$. But increased country j's welfare decreases country i's welfare, when countries $i$ and $j$ are enemies. Because of this decreased welfare the actor country increases conflict with i. This phenomenon would be illustrated in Figure 9 by an upward shift of the marginal benefit curve and thus imply that conflict with country $\mathrm{i}$ increases. One can apply the above notions about how trading with a third party affects bilateral political interactions to other situations.

\subsubsection{An Application to Tariffs}

An import duty country i imposes on an actor's exports is a tariff. As a result, trade decreases because of the higher prices paid by importers. Based on the previous gains 
from trade analysis, decreased trade means increased conflict. But it is possible that tariffs can also affect third party conflict. Whereas most literature deals with multilateral sanctions in the sense that several countries impose a tariff, e.g., Mansfield (1995), Martin (1992) and Mastanduno (1992), the analysis used here assesses how a tariff affects conflict even on countries that don't impose a tariff. As shown above, trade between an actor and target can alter conflict between the actor and third parties. Since tariffs alter actor-target trade, they may also influence an actor's conflict with third parties. According to the theory, actor-target conflict depends on the relationship between the target and the third party. Recall that trade with a foe-of-a-friend increases conflict while trade with a friend-of-a-friend diminishes conflict. As such, a third-party imposed tariff can decrease conflict if the target and third party are enemies, whereas conflict can increase if the target and third party are friends.

\subsubsection{An Application to Foreign Aid}

How foreign aid influences political relations is a topic often considered by political scientists and economists [e.g., Abegunrin (1990), Cashel-Cordo and Craig (1997), Holsti (1982), Orr (1989/1990), Richardson (1978)]. Most view foreign aid in a bilateral setting, a framework in which foreign aid is simply considered a transfer payment from one country to another but often with requirements to purchase imports from the aid provider. To the extent that foreign aid simply becomes a subsidy to purchase a beneficiary's products, one can analyze foreign aid through its impact augmenting trade. Again, applying the analysis increased trade implies decreased conflict, but just like with tariffs, it is possible that foreign aid can alter third party political interactions. 
Again refer to the theory behind Figures 8 and 9. Actor-target conflict depends on the relationship between the target and the third party. Trade with a foe-of-a-friend increases conflict while trade with a friend-of-a-friend diminishes conflict. As such, third party foreign aid can increase conflict if the target and third party are enemies, whereas conflict can decrease if the target and third party are friends. The extent depends on the gains from trade and degree of friendship.

\subsubsection{An Application to Contiguity}

Many find that contiguity increases war proneness [Barbieri (1996), Bremer (1992a), Diehl (1985), Gleditsch (1995), Gochman (1991), and Goertz and Diehl (1992)]. Indeed, one would be hard pressed to find noncontiguous countries that engaged in militarized dispute prior to the $18^{\text {th }}$ century. The relationship is so well established that some current research addresses why neighbors fight, rather than whether they fight (i.e., Vazquez (1995). On the other hand, it is well known that neighboring nations take advantage of small transportation costs to engage in more bilateral trade [Anderson (1979); Arad and Hirsch (1981); Deardorff (1984); Gowa (1994); Tinbergen (1962)]. According to the trade-conflict model, greater trade induces less conflict, thus appearing to contradict the empirical findings regarding contiguity and war. However, rather than contradicting each other, the two models may be complementary.

Analyzing the effects of contiguity is difficult because ignoring the effects of trade can lead to an omitted variable bias. One must isolate each effect, otherwise one runs the risk of underestimating conflict between neighboring countries. Despite appearing high to begin with, current conflict measures might underestimate true conflict among 
neighboring states because they ignore the mitigating effects of trade. Thus while neighbors fight, they might engage in even more conflict were it not for the greater trade levels induced by their proximity to each other. But greater trade between neighboring countries can affect relations with more distant countries, as well.

Again refer back to the analysis regarding third parties. Trade with a friend-of-a-friend fosters less conflict than otherwise, while trade with a foe-of-a-friend brings greater conflict. As such, given the greater trade exhibited between neighbors, an actor should display less conflict towards friends of neighboring countries and more conflict towards a neighbor's rivals.

\section{Conclusion}

The proposition that international trade specifically, and economic interdependence in general reduces conflict between nations has a long tradition in the history of economic thought. The argument proposed is that trade leads to welfare gains that countries do not want to jeopardize losing by engaging in trade-disruptive activities such as wars or other forms of conflict. Yet, until fairly recent times economists have not applied some of the modern tools of economics to explore this proposition. This is surprising given the large cost to society of diverting resources towards a purely predatory or redistributive motive instead of productive activity. Given the slow pace of economic development in large parts of the world ravaged by conflict, and the dim prospects of a convergence of their income with those of the developed world, it seems the incentives to explore this topic is of some urgency.

Our review of the empirical literature on the conflict-trade relationship indicates that researchers use several different historical data sets to measure conflict. These are the COW, MIDS, COPDAB and more recently VAR. There also different ways that 
trade is measured. Yet, the overwhelming evidence indicates that trade reduces conflict regardless of the proxies used to capture the gains from trade and conflict. Our preference is for using events data because this data contain both information on conflict, as well as on cooperation between nations. As such, it allows for exploring a continuum of international interactions and not just the extreme endpoint of outright war.

We also conclude that to a large extent the empirical evidence that has been found that democracies are less prone to fight with other democracies can be explained by accounting for the larger trade relationship between democracies. Furthermore, more recent empirical results show that foreign direct investment plays a similar role as trade in affecting international interactions. More specifically, we find that the flow of FDI has reduced the degree of international conflict and encouraged cooperation between dyads during the period of the late 1980 and the decade of the 90 s. This is an especially important result since one of the main characteristics of globalization has been the reduction of barriers to international capital flows and as a consequence the amounts of capital flows have expanded enormously dwarfing those of trade flows.

The policy implication of our finding is that further international cooperation in reducing barriers to both trade and capital flows can promote a more peaceful world. Furthermore, efforts at democracy while laudable should not have the expected pacifying effects between neighbors unless the appropriate institutions are developed simultaneously to promote trade and capital flows between nations. It is by this vehicle that resources will be freed to address more urgent needs in the international system. 


\section{References}

Abegunrin, O. (1990), Economic Dependence and Regional Cooperation in Southern Africa: SADCC and South Africa in Confrontation (Edwin Mellen Press, Lewiston, NY).

Acemoglu, D., S. Johnson and J. Robinson (2003), The rise of Europe: Atlantic trade, institutional change and economic growth, C.E.P.R. Discussion Papers, CEPR Discussion Papers: 3712.

Alesina, A. and E. Spolaore (2003), The Size of Nations, (The MIT Press, Cambridge, MA and London, England).

Altfield, M. (1984), The decision to ally: a theory and test, Western Political Quarterly 37:523-544.

Altfield, M. and B. Bueno de Mesquita (1979), Choosing sides in wars, International Studies Quarterly 23:87-112.

Anderson, J. (1979), A theoretical foundation for the gravity equation, American Economic Review 69:106-116.

Anderton, C. H. and J. Carter (2001), The impact of war on trade: an interrupted timeseries study, Journal of Peace Research 38: 445-457.

Angell, Sir N. (1913), The Great Illusion: A Study of the Relation of Military Power To National Advantage, (Garland Publishing, New York).

Arad, R. W. \& S. Hirsch, (1981), Peacemaking and vested interests: international economic transactions, International Studies Quarterly 25:439-468.

Armington, P. (1969), The geographic pattern of trade and the effects of price changes, IMF Staff Papers 16:179-99.

Azar, E. (1980), The conflict and peace data bank (COPDAB) project, Journal of Conflict Resolution 24:143-152.

Azar, E.. and J. D. Ben-Dak. (1975), Theory and Practice of Events Research: Studies in Inter-nation Actions and Interactions, (Gordon and Breach Science Publishers, New York).

Barbieri, K. (1996), Economic interdependence: a path to peace or a source of interstate conflict?, Journal of Peace Research 33:29-50.

Barbieri, K. (2002), The Liberal Illusion: Does Trade Promote Peace?, (University of Michigan Press, Ann Arbor). 
Barbieri, K. and J. S. Levy (1999), Sleeping with the enemy: the impact of war on trade, Journal of Peace Research 36:463-479.

Barbieri, K. and G. Schneider (1999), Globalization and peace: assessing new directions in the study of trade and conflict, Journal of Peace Research 36:387-404.

Bearce, D. and E. Fisher (2002), Economic geography, trade, and war, Journal of Conflict Resolution 46:365-393.

Bearce, D. H. and S. Omori (2005), How do commercial institutions promote peace?, Journal of Peace Research 42:659-78.

Beck, N. (2003), Modeling dynamics in the study of conflict: a comment on Oneal and Russett, in: G. Schneider, K. Barbieri and P. Gleditsch, eds.,Globalization and Armed Conflict (Rowman \& Littlefield, New York).

Blainey, G. (1988), The Causes of War. (Macmillan Press, Basingstoke).

Blonigen, B. (2005), A review of the empirical literature on FDI determinants, NBER Working Paper No.11299.

Bremer, S. (1992a), Dangerous dyads: conditions affecting the likelihood of interstate war, 1816-1965, Journal of Conflict Resolution 36:309-341.

Bremer, S. (1992b), Are democracies less likely to win wars?, Paper Presented at the Annual Meetings of the American Political Science Association, Chicago.

Bremer, S. (1993), Democracy and militarized interstate conflict, 1816-1965, International Interactions 18:231-249.

Bright, J. (1883), Speeches on Questions of Public Policy, (Macmillan, London).

Bueno de Mesquita, B., M.T. Koch, and R.M. Siverson (2004), Testing competing institutional explanations of the democratic peace: the case of dispute duration, Conflict Management and Peace Science 21:255-67.

Bueno de Mesquita, B. and D. Lalman (1992), War and Reason: Domestic and International Imperatives, (Yale University Press, New Haven).

Caruso, R. (2006), A trade institution as a peaceful institution? A contribution to integrative theory, Conflict Management and Peace Science 23:53-72.

Cashel-Cordo, P. and S. G. Craig (1997), Donor preferences and recipient fiscal behavior: a simultaneous analysis of foreign aid, Economic Inquiry 35: 653-671. 
Cederman, L.E. and R. M. Penubarti (2001), Exploring the dynamics of the democratic peace, Journal of Conflict Resolution 45:818-33.

Chan, S. (1984), Mirror, mirror on the wall, are the freer countries more pacific?, Journal of Conflict Resolution 28:617-48.

Cobden, R. (1995), The Political and Economic Works of Richard Cobden, (Routledge/Thoemmes Press, London).

Crescenzi, M. (2000), Exit Stage Market: Market Structure, Interstate Economic Interdependence and Conflict, PhD Dissertation University of Illinois, UrbanaChampaign.

Crucé, E. (1623), Le Nouveau Cynee, ou, Discours des Occasions et Moyens d'establir une Paix Generale et la Liberté du Commerce par tout le Monde, (Chez Jacques Villery, Paris).

de Montesquieu, B. (1900 originally written in 1750), The Spirit of Laws, translated by Thomas Nugent, (Collier Press, New York).

Deardorff, A. V. (1984), Testing trade theories and predicting trade flows, in: Ronald W. Jones and Peter B. Kenen, eds., Handbook of International Economics (NorthHolland Press, Amsterdam) 467-517.

Diehl, P. F. (1985), Contiguity and military escalation in major power rivalries, 18161980, Journal of Politics 47:1203-1211.

Dixon, W. J. (1989), Political democracy and war: a new look at an old problem, Paper presented at the International Studies Association Conference, London, England.

Dixon, W. J. (1998), Dyads, disputes and the democratic peace, in Wolfson, Murray, ed., The Political Economy of War and Peace (Kluwer Academic, Boston, Dordrecht and London) 103-26.

Domke, W. K. (1988), War and the Changing Global System, (Yale University Press, New Haven).

Dorussen, Han (1999), Balance of power revisited, multi-actor models of trade and conflict, Journal of Peace Research 36:443-462.

Doyle, M. W. (1986), Liberalism and world politics, American Political Science Review 80:1151-1169.

Doyle, M. W. (1997), Ways of War and Peace: Realism, Liberalism, and Socialism. (W.W. Norton, New York). 
Doyle, M. W. (2005), Three pillars of the liberal peace, American Political Science Review 99: 463-66

Ember, C., M. Ember, and B. Russett (1992), Peace between participatory polities: A cross-cultural test of the democracies rarely fight each other hypothesis," World Politics 44:573-599.

Erasmus, D. (1981), Enchiridion militis Christiani: an English version, A. M. O'Donnell, ed., (Published for the Early English Text Society by the Oxford University Press, Oxford and New York).

Ethier, W. and A. Ray (1979), Gains from trade and the size of a country, Journal of International Economics 9:127-129.

Eyerman, J. and R. H. Robert (1996), An empirical test of the audience cost proposition: democracy speaks louder than words, Journal of Conflict Resolution 40:597-616.

Farber, H. and J. Gowa (1997), Common interests or common polities: reinterpreting the democratic peace, Journal of Politics 59:393-417.

Feng, Y (1994), Trade, conflict, and alliances, Defence and Peace Economics 5: 301-313.

Findlay, R. (2001), Trade and Conflict, Paper Presented at the American Economic Association Annual Conference, New Orleans.

Frankel, J. A. and D. Romer (1996), Trade and Growth: An Empirical Investigation, NBER Working Paper No. 5476.

Froot, K. (1995), Foreign Direct Investment, (University of Chicago Press, Chicago and London).

Gartzke, E. (1998), Kant we all just get along? opportunity, willingness, and the origins of the democratic peace, American Journal of Political Science 42:1-27.

Gartzke, E. and Q. Li (2001), War and the Invisible Hand: Positive Political Externalities of Economic Globalization, Paper presented on the International Relations Workshop, University of Michigan.

Gasiorowski, M. and S. Polachek (1982), "Conflict and interdependence: east-west trade and linkages in the era of detente," Journal of Conflict Resolution 26:709-730.

Gelpi, C. and J. Grieco (2003), Economic interdependence, the democratic state, and the liberal peace, in E. Mansfield and B. Pollins, eds., Economic Interdependence and International Conflict: New Perspectives on an Enduring Debate (University of Michigan Press, Ann Arbor). 
Gilpin, R. (1975), U.S. Power and the Multinational Corporation: The Political Economy of Foreign Direct Investment (Basic Books, New York).

Gilpin, R. (2001), Global Political Economy: Understanding the International Economic Order, (Princeton University Press, Princeton).

Gleditsch, N. P. (1995), Geography, democracy and peace, International Interactions 20:297-324.

Gochman, C. S. and Z. Maoz (1984), Militarized interstate disputes, 1816-1976, Journal of Conflict Resolution 28:585-615

Gochman, C. S. (1991), Interstate metrics: conceptualizing, operationalizing and measuring the geographic proximity of states since the Congress of Vienna, International Interactions 17:93-112.

Goertz, G. and P. F. Diehl (1992), Territorial Changes and International Conflict. (Routledge, London).

Goldstein, J. S. (1992), A conflict-cooperation scale for WEIS event data, Journal of Conflict Resolution 36:369-385.

Goldstein, M. and M. Kahn (1985), Income and price elasticities in foreign trade, in T. Jones and P. Kenen, eds., Handbook of International Trade, Volume 2 (North Holland Press, Amsterdam).

Gowa, J. (1989), Bipolarity, multipolarity and free trade, The American Political Science Review 83:1245-1256.

Gowa, J. (1994), Allies, Adversaries, and International Trade, (Princeton University Press, Princeton).

Greggs, P. and A. Banks (1965), Dimensions of political systems: factor analysis of a cross-polity survey, American Political Science Review: 602-14.

Grossman, G. and E. Helpman (2002), Interest Groups and Trade Policy, (Princeton University Press, Princeton).

Grossman, H. and J. Mendoza (2001), Peaceful Annexation or Conquest: The Economics of Empire Building, paper presented at the American Economic Association Meetings, New Orleans.

Gurr, T. R. (1974), Civil Strife Events, 1955-1970 (ICPSR 7531), Inter-University Consortium for Political and Social Research, Ann Arbor. 
Haas, M. (1965), Societal approaches to the study of war, Journal of Peace Research 2:307-23.

Haas, R. D. and A. G. Turner (1988), The world trade Model: revised estimates, International Monetary Fund Working Paper WP/8/850.

Hagan, J. (1987), Regimes, political oppositions and the comparative analysis of foreign policy, in New Directions in the Study of Foreign Policy, Charles Hermann et al. eds., (Allen and Unwin, Boston) 339-265.

Head, A. C. (1995), Country size, aggregate fluctuations, and international risk sharing, Canadian Journal of Economics 28:1096-1119.

Hegre, H. (2003), Development and the liberal peace: what does it take to be a trading state, in G. Schneider, K. Barbieri, and N. P. Gleditsch, eds., Globalization and Armed Conflict (Rowman \& Littlefield, New York and Oxford) 205-232.

Henderson, E. (2002), Democracy and War: The End of an Illusion? (Lynne Rienner, Boulder, $\mathrm{CO}$ ).

Hermann, C., M. A. East, M. G. Hermann, B. G. Salmore, and S. A. Salmore (1973), CREON: A Foreign Events Data Set. (Sage Publications, Beverly Hills).

Hess, G. D. and O. Athanasios (2001), War and democracy, Journal of Political Economy 109:776-810.

Hirschman, A. O., [(1945) (1980)], National Power and the Struggle of Foreign Trade. (University of California Press, Berkeley).

Hirshleifer, J. (1995), Anarchy and its breakdown. Journal of Political Economy 103:2652.

Holsti, K. J. (1982), Why Nations Realign: Foreign Policy Restructuring in the Post War World, (Allen and Unwin, Boston).

Holsti, Ole, T. Hopmann and J. Sullivan (1973), Unity and Disintegration in International Alliances: Comparative Studies, (Wiley, New York).

Hooper, P., K. Johnson, and J. Marquez (1998), Trade Elasticities for G-7 Countries, International Finance Discussion Paper Number 609, Board of Governors of the Federal Reserve.

Kant, I. (1795), Eternal Peace and Other International Essays, translated by W. Hastie, (The World Peace Foundation, Boston). 
Kegley, C. (1975), International Events and the Comparative Analysis of Foreign Policy (University of South Carolina Press, Columbia).

Kegley, C. W., Jr. and M. Hermann (1996), How democracies use intervention: a neglected dimension in studies of the democratic peace, Journal of Peace Research 33:309-22.

Keohane, R. and J. Nye (1989), Power and Interdependence: World Politics in Transition, (Harper Collins, New York).

Keshk, O., B. Pollins and R. Reuveny (2004), Trade still follows the flag: the primacy of politics in a simultaneous model of interdependence and armed conflict, The Journal of Politics 66:1155-1179.

Keynes, J. M. (1920), The Economic Consequences of the Peace, (Harcourt, Brace and Howe, New York).

Kim, C.H. (1991), Third-party participation in wars, Journal of Conflict Resolution 35:659-677.

Kim, S.Y. (1995), Bilateral Conflict and Trade, 1948-86: The Role of Economic Interdependence in Conflict Processes, Paper Presented at the American Political Science Association Conference, Chicago, IL.

King, G. and W. Lowe (2003), An automated information extraction tool for international conflict data with performance as good as human coders: a rare events evaluation design, International Organization 57:617-642.

Kinsella, D. (2005), No rest for the democratic peace, American Political Science Review 99:453-57.

Krugman, P. (1995), Economic Conflicts Among Nations: Perceptions and Reality, Paper presented at the AEA Convention, Washington, D.C.

Lake, D. (1992), Powerful pacifists: democratic states and war, American Political Science Review 86:24-37.

Levy, G. and R. Razin (2004), It takes two:an explanation for the democratic peace, Journal of the European Economic Association 2:1-29.

Levy, J. (1983), War in the Modern Great Power System, 1495-1975, (University of Kentucky Press, Lexington).

Levy, J. (1989), The causes of war: a review of theories and evidence, in Behavior, Society and Nuclear War, Vol 1 ed., P.C. Tetlock, et al. (Oxford University Press, Oxford and New York) 209-333. 
MacMillan, J. (March 2003), Beyond the separate democratic peace: review essay, Journal of Peace Research 40:233-43.

Mansfield, E. D. (1994), Power, Trade and War, (Princeton University Press, Princeton).

Mansfield, E. D. (1995), International institutions and economic sanctions, World Politics 47:575-605.

Mansfield, E..D. (2004), International Conflict and the Global Economy, (Cheltenham, UK and Northampton, MA, USA).

Mansfield, E. D. and J. Pevehouse (2000), Trade blocs, trade flows, and international conflict, International Organization 54:775-808.

Mansfield, E. D. and B.M. Pollins (2001), The study of interdependence and conflict: recent advances, open questions, and directions for future research, Journal of Conflict Resolution 45:834-59.

Mansfield, E. D. and B. M. Pollins (2003), New Perspectives on Economic Exchange and Armed Conflict, (University of Michigan Press, Ann Arbor).

Maoz, Z. and N. Abdelali (1989), Regime types and international conflict: 1816-1976, Journal of Conflict Resolution 33:3-35.

Maoz, Z. and B. Russett (1992), Alliances, contiguity, wealth, and political stability: is the lack of conflict between democracies a statistical artifact?, International Interactions 17:245-267.

Maoz, Z. and B. Russett (1993), Normative and structural causes of democratic peace, American Political Science Review 87:624-638.

Marquez, J. (1988), Income and Price Elasticities of Foreign Trade Flows: Econometric Estimation and Analysis of the U.S. Trade Deficit, Board of Governors of the Federal Reserve System International Finance discussion Papers, No. 324.

Marquez, J. (1990), Bilateral trade elasticities, Review of Economics and Statistics 72:70-77.

Martin, L. (1992), Coercive Cooperation: Explaining Multilateral Economic Sanctions. (Princeton University Press, Princeton).

Martin, P., T. Mayer, and M. Thoenig (2005), Make Trade not War? C.E.P.R. Discussion Papers, CEPR Discussion Papers: 5218. 
Mastanduno, M. (1992), Economic Containment: COCOM and the Politics of East-West Trade. (Cornell University Press, Ithaca, NY).

McClelland, C. (1999), World Event/Interaction Survey (Weis) Project, 1966-1978 [Computer file]. Conducted by Charles McClelland, University of Southern California. 3rd ICPSR ed. (Ann Arbor, MI: Inter-university Consortium for Political and Social Research).

McDonald, P. (2004), Peace through trade or free trade?, Journal of Conflict Resolution 48:547-72.

McMillan, S. (1997), Interdependence and conflict, Mershon International Studies Review 41:33-58.

Mintz, A. and N. Geva (1993), Why don't democracies fight each other? an experimental study, Journal of Conflict Resolution 37:484-503.

Morgan, T. C. and S. H. Campbell (1991), Domestic structure, decisional constraints, and war, Journal of Conflict Resolution 35:187-211.

Morgan, T. C. and V. Schwebach (1992), Take two democracies and call me in the Morning: a prescription for peace, International Interactions 17:305-320.

Morrow, J. D. (1991), Alliances and asymmetry: an alternative to the capability aggregation model of alliances, American Journal of Political Science 35:904933.

Morrow, J. D. (1997), When do 'relative gains' impede trade?, Journal of Conflict Resolution 41:12-37.

Morrow, J. D. (1999), How could trade affect conflict?, Journal of Peace Research 36: 481-489.

Mousseau, M. (2005), Comparing new theory with prior beliefs: market civilization and the democratic peace, Conflict Management and Peace Science 22:63-77.

Mousseau, M. and Y. Shi. (1999), A test for reverse causality in the democratic peace relationship, Journal of Peace Research 36:639-63.

Nye, J. S. (1974), Multinationals: the game and the rules: multinational corporations in world politics, Foreign Affairs.

Oneal, J. R., F. H. Oneal, Z. Maoz \& B. Russett (1996), The liberal peace: interdependence, democracy, and international conflict, 1950-86, Journal of Peace Research 33:11-28. 
Oneal, J. R. and J. L. Ray (1997), New tests of the democratic peace: controlling for economic interdependence, 1950-1985, Political Research Quarterly 50:751-775.

Oneal, J. R. and B. M. Russett (1996), The classical liberals were right: democracy, interdependence, and conflict, 1950-1985, International Studies Quarterly 41:267294.

Oneal, J. R and B. M. Russett (1999), Assessing the liberal peace with alternative specifications: trade still reduces conflict, Journal of Peace Research 36:423-42

Orr, R. M. (1989/1990), Collaboration or conflict? Foreign aid and U.S.-Japan relations, Pacific Affairs 62:476-489.

Polachek, S. W. (1978), Dyadic dispute: an economic perspective, Papers of the Peace Science Society 28:67-80.

Polachek, S. W. (1980), Conflict and trade, Journal of Conflict Resolution 24: 55-78.

Polachek, S. W. (1992), Conflict and trade: an economics approach to political international interactions, in W. Isard and C. H. Anderton, eds., Economics of Arms Reduction and the Peace Process, (Elsevier Science Publishers, New York) 89-120.

Polachek, S.W. (1994a), Peace economics: a trade theory perspective, Peace Economics, Peace Science and Public Policy 1:12-15.

Polachek, S. W. (1997), Why democracies cooperate more and fight less: the relationship between international trade and cooperation, Review of International Economics 5:295-309.

Polachek, S. W. (2002a), Conflict and Trade: An Economics Approach to Political International Interactions with Special Reference to US-China Relations, Paper presented at the Sino-American Economic Relations under the WTO Conference, Lingnam University, Hong Kong.

Polachek, S. W. (2002b), Trade-based interactions: an interdisciplinary perspective, Conflict Management and Peace Science 19:1-21.

Polachek, S. W. (2003), Multilateral interactions in the trade-conflict model, in G. Schneider, K. Barbieri, and N. P. Gleditsch, eds., Globalization and Armed Conflict, (Rowman \& Littlefield, New York and Oxford).

Polachek, S. W. (2004), What can we learn about the decline in U.S. union membership from international data, in P. V. Wunnava, ed., The Changing Role of Unions (M.E. Sharpe, Armonk, NY and London, England) 362-377. 
Polachek S.W. and M. K. Kim (1994b), Panel estimates of the gender earnings gap: individual-specific intercept and individual-specific slope models, Journal of Econometrics 61:23-42.

Polachek, S. W. and J. A. McDonald (1992), Strategic trade and the incentive for cooperation, in M. Chatterji and L. Forcey, eds, Disarmament, Economic Conversion, and the Management of Peace (Praeger Press, New York) 273-84.

Polachek, S. W. and J. Robst (1998), Cooperation and conflict among democracies: why do democracies cooperate more and fight less, in M. Wolfson, ed., The Political Economy of War and Peace, (Kluwer, Boston) 127-154.

Polachek, S. W., J. Robst and Y.C. Chang (1999), Liberalism and interdependence: extending the trade-conflict model," Journal of Peace Research 36:405-422.

Polachek, S., C. Seiglie, and J. Xiang (2005), Globalization and international conflict: can FDI increase peace?, Working Paper Rutgers University, Newark: 1-35.

Pollins, B. (1989a), Does trade still follow the flag?, American Political Science Review 83: $465-480$.

Pollins, B. (1989b), Conflict cooperation and commerce: the effect of international political interactions, American Journal of Political Science 33:737-761.

Powell, R. (1991), Absolute and relative gains in international relations, American Political Science Review 85:1303-1320.

Ray, J. L. (1993), War between democracies: rare or nonexistent?, International Interactions 18:251-276.

Ray, J. L. (1997), The democratic path to peace, Journal of Democracy 8:49-67.

Rayome, D. and J. C. Baker (1995), Foreign direct investment: A review and analysis of the literature, International Trade Journal 9:3-37.

Reuveny, R. (1999), The trade conflict debate: a survey of theory, evidence and future research, Peace Economics, Peace Science and Public Policy 6:23-49.

Reuveny, R. (2001), Disaggregated trade and conflict: exploring propositions in a simultaneous framework, International Politics 38:401-28.

Reuveny, R. and H. Kang (1996), International trade, political conflict/cooperation, and granger causality, American Journal of Political Science 40:943-70.

Reuveny, R. and H. Kang (1998), Bilateral trade and political conflict/cooperation: do goods matter?, Journal of Peace Research 35:581-602. 
Reuveny, R. and H. Kang (2003), A simultaneous-equations model of trade, conflict, and cooperation, Review of International Economics 11:279-95.

Ricardo, D. (1981 originally published in 1817), The Principles of Political Economy and Taxation (Cambridge University Press, Cambridge).

Richardson, L. F. (1960), Arms and Insecurity, A Mathematical Study of the Causes and Origins of War, (The Boxwood Press, Pittsburgh and Quadrangle Books, Chicago).

Richardson, N. R. (1978), Foreign Policy and Economic Dependence, (The University of Texas Press, Austin).

Robbins, L. (1968), The Economic Causes of War, (Howard Fertig Press, New York).

Rosato, S. (2003), The flawed logic of democratic peace theory, American Political Science Review 97:585-602.

Rousseau, J. J. (2005), The Plan for Perpetual Peace, On the Government of Poland, and Other Writings on History and Politics, (Dartmouth College Press and University Press of New England, Hanover, N.H.).

Rummel, R. (1968), The relationship between national attributes and foreign conflict behavior, in J.D. Singer, ed., Quantitative International Politics: Insights and Evidence (Free Press, New York) 187-214.

Rummel, R. J. (1975), National Attributes and Behavior (Sage Publications, Beverly Hills).

Rummel, R. J. (1979a), The Dimensions of Nations (Sage Publications, Beverly Hills) .

Rummel, R. J. (1979b), War, Power, Peace, Volume 4 of Understanding Conflict and War, (Sage Press, Beverly Hills).

Rummel, R. J. (1987), On Vincent's view of freedom and international conflict, International Studies Quarterly 31:113-117.

Russett, B. (1967), International Regions and the International System, (Rand McNally, Chicago).

Russett, B. (1989), Democracy and peace, in B. Russett et al. eds., Choices in World Politics, (W.H. Freeman, New York).

Russett, B. and W. Antholis (1992), Do democracies fight each other? evidence from the Peloponnesian War, Journal of Peace Research 29:415-34. 
Russett, B. and R. J. Monsen (1975), Bureaucracy and polyarchy as predictors of performance: a cross-national examination, Comparative Political Studies 8: $5-31$.

Russett, B. and J. Oneal (2001), Triangulating Peace: Democracy, Interdependence, and International Organizations (Norton, New York).

Sabrosky, A. N. (1980), Interstate alliances: their reliability and the expansion of war, in: J. David Singer, ed., The Correlates of War: II. (Free Press, New York) 161-198.

Saggi, K. (2002), Trade, foreign direct investment, and international technology transfer: a survey, World Bank Research Observer 17:191-235.

Sayrs, L. W. (1990), Expected utility and peace science: an assessment of trade and conflict, Conflict Management and Peace Science 11:17-44.

Schelling, T. C. (1960), The Strategy of Conflict. (Harvard University Press, Cambridge, MA).

Schneider, G., K. Barbieri and N. P. Gleditsch (2003), Does globalization contribute to peace? a critical survey of the literature, in: G. Schneider, K. Barbieri and N. P. Gleditsch,eds., Globalization and Armed Conflict (Rowman \& Littlefield, New York and Oxford) 3-29.

Schrodt, P. (1995), Event data in foreign policy analysis, in: Laura Neack, Jeanne A.K. Hey, Patrick J. Haney, eds., Foreign policy analysis: continuity and change in its second generation, (Prentice Hall, Englewood Cliffs, NJ).

Seiglie, C. (1992), Determinants of military expenditures, in: W. Isard and C. Anderton, eds., Economics of Arms Reduction and the Peace Process, (North-Holland, Amsterdam) 183-202.

Seiglie, C. (1996), The Effects of Trade on Military Spending, paper presented at the PSSI meetings, Rice University, Houston.

Seiglie, C. (2005), Openness of the economy, terms of trade and arms, Rutgers University Newark Working Paper \#2005-008:1-37.

Simon, M. and E. Gartzke (1996), Political system similarity and the choice of allies, Journal of Conflict Resolution 40:617-635.

Singer, J. D. and M. Small (1966a), Formal alliances, 1815-1939: a qualitative description, Journal of Peace Research 3:1-32. 
Singer, J. D. and M. Small (1966b), National alliance commitments and war involvement, 1815-1945, Peace Research Society (International) Papers 5:109-40.

Singer, J. D. and M. Small (1972), The Wages of War, 1816-1965: A Statistical Handbook, (Wiley, New York).

Siverson, R. and J. Emmons (1991), Birds of a feather: democratic political systems and alliance choices in the twentieth century, Journal of Conflict Resolution 35:285306.

Siverson, R. and J. King (1979), Alliances and the expansion of war, in: J. David Singer and Michael D. Wallace, eds., To Augur Well: Early Warning Indicators in World Politics, (Sage, Beverly Hills, CA) 37-50.

Siverson, R. and J. King (1980), Attributes of national alliance membership and war participation, 1815-1965, American Journal of Political Science 24:1-15.

Slantchev, Branislav, Anna Alexandrova, and Erik Gartzke (2005), Probabilistic causality, selection bias, and the logic of the democratic peace, American Political Science Review 99:459-62.

Small, M. and J. D. Singer (1976), The war proneness of democratic regimes, 1816-1965, Jerusalem Journal of International Relations 1:50-69.

Small, M. and J.D. Singer (1982), Resort to Arms: International and Civil Wars, 18161980. (Sage Publications, Beverly Hills).

Starr, H. (1992), Democracy and war: choice, learning, and security communities, Journal of Peace Research 29:207-213.

Streit, C. (1938), Union Now: A Proposal for a Federal Union of the Leading Democracies, (Harper Press, New York).

Taylor, C. L. and M. C. Hudson (1972), World Handbook of Political and Social Indicators, 2nd ed. (Yale University Press, New Haven, CT).

Thompson, P. G. (2003), Foreign direct investment and war: Economic deterrence to armed conflict. Ph.D. Dissertation, UCLA.

Thompson, W. R. and R. Tucker (1997), A tale of two democratic peace critiques, Journal of Conflict Resolution 41:428-54.

Tinbergen, J. (1962), Shaping the World Economy: Suggestions for an International Policy, (Twentieth Century Fund, New York). 
Vasquez, J. (1995), Why do neighbors fight? proximity, interaction, or territoriality," Journal of Peace Research 32:277-293.

Vernon, R. (1971), Sovereignty at Bay: The Multinational Spread of US Enterprises, (Basic Books, New York).

Vincent, J. (1987), On Rummel's omnipresent theory, International Studies Quarterly 31:119-26.

Viner, J. (1937), Studies in the Theory of International Trade, 1st ed. (Harper \& Brothers, New York, London).

Vousden, N. (1990), The Economics of Trade Protection, (Cambridge University Press, Cambridge).

Wallenstein, P. (1973), Structure and War: On International Relations 1920-1968, (Raben and Sjögren, Stockholm).

Watkins, J. (1942), Democracy and international organization: the experience of the League of Nations, American Political Science Review 36:1136-41.

Weeded, E. (1984), Democracy and war involvement, Journal of Conflict Resolution 28:56-69.

Wright, Q. (1942), A Study of War, (University of Chicago Press, Chicago).

Zeng, K. (2004), Trade Threats, Trade Wars: Bargaining, Retaliation, and American Coercive Diplomacy, (University of Michigan Press, Ann Arbor).

Zinnes, D. A. (2004), Constructing political logic: the democratic peace puzzle, Journal of Conflict Resolution 48:430-54. 


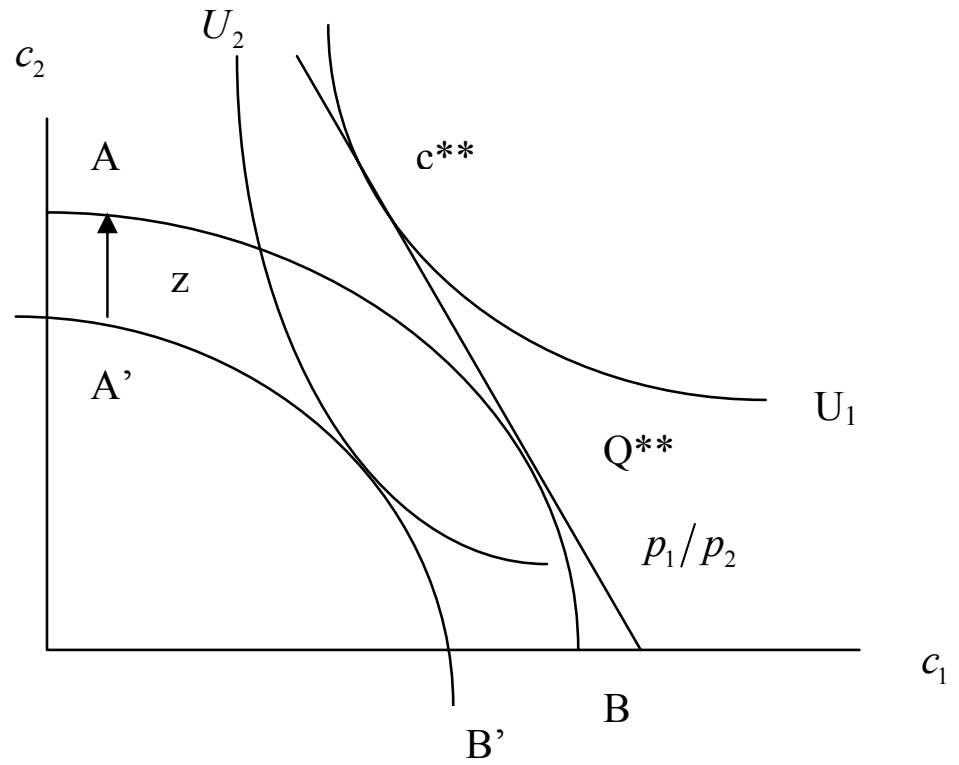

Figure 1: Gains From Trade 


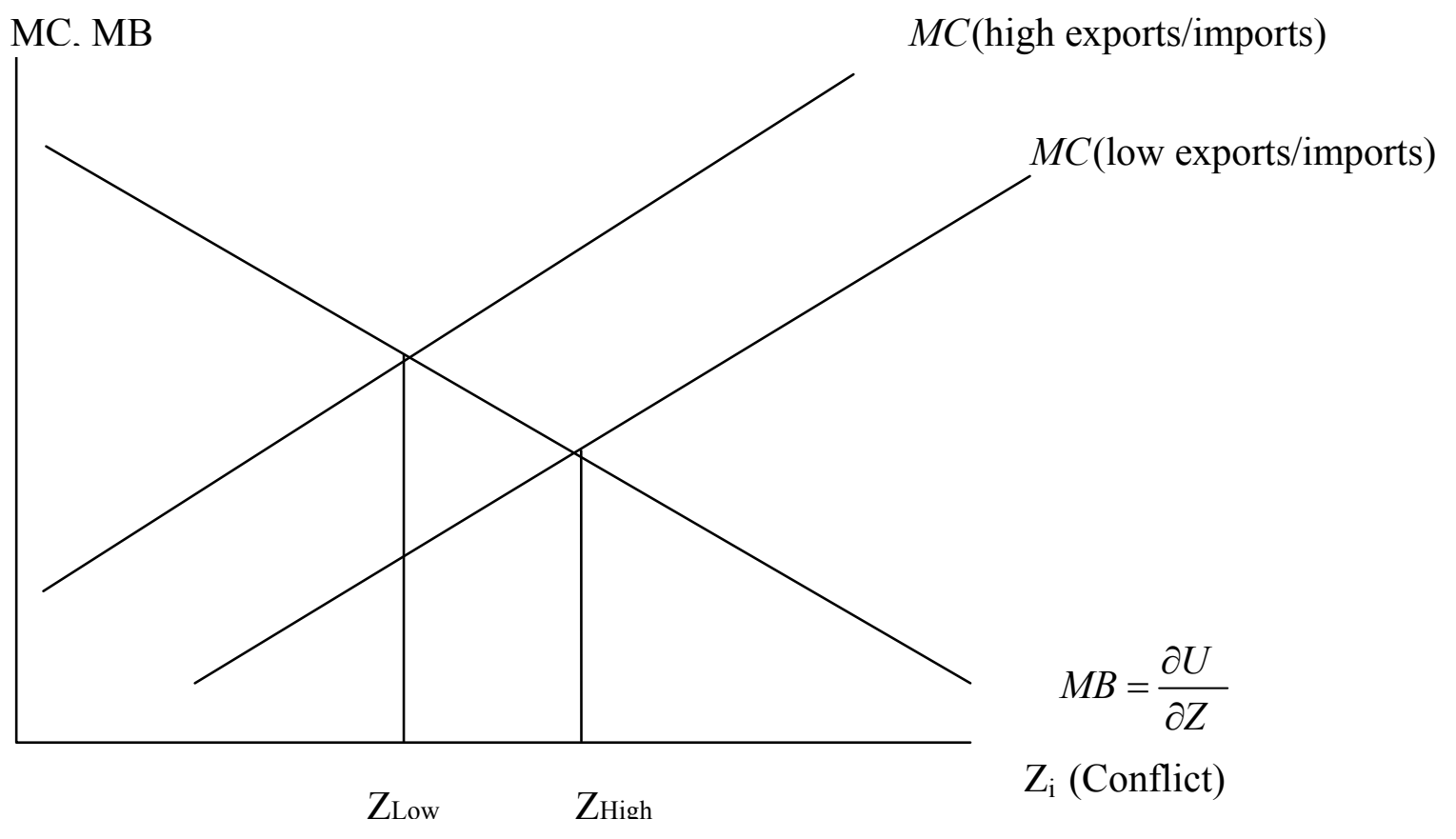

Figure 2

Equilibrium Conflict 


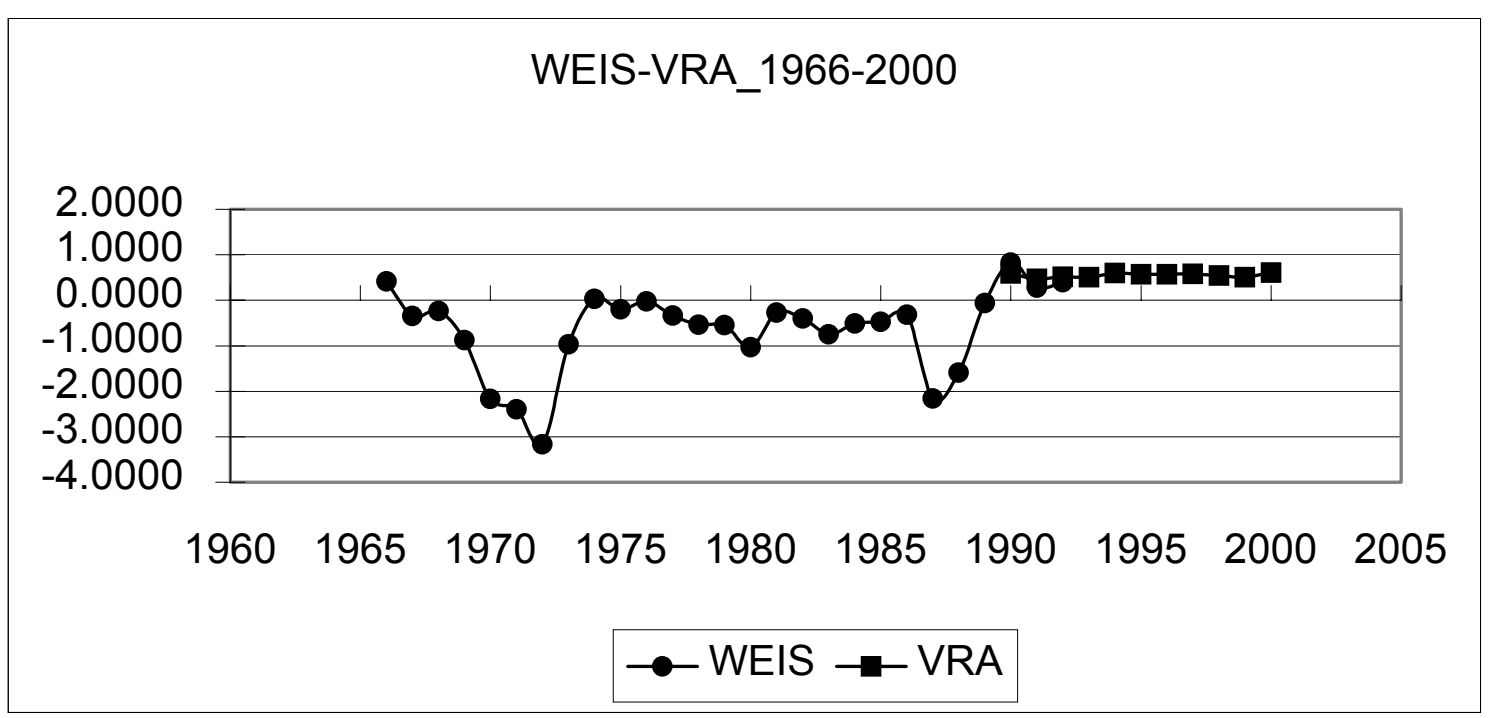

Figure 3

WEIS and VRA Aggregate Conflict Data by Year 
USA-WEIS

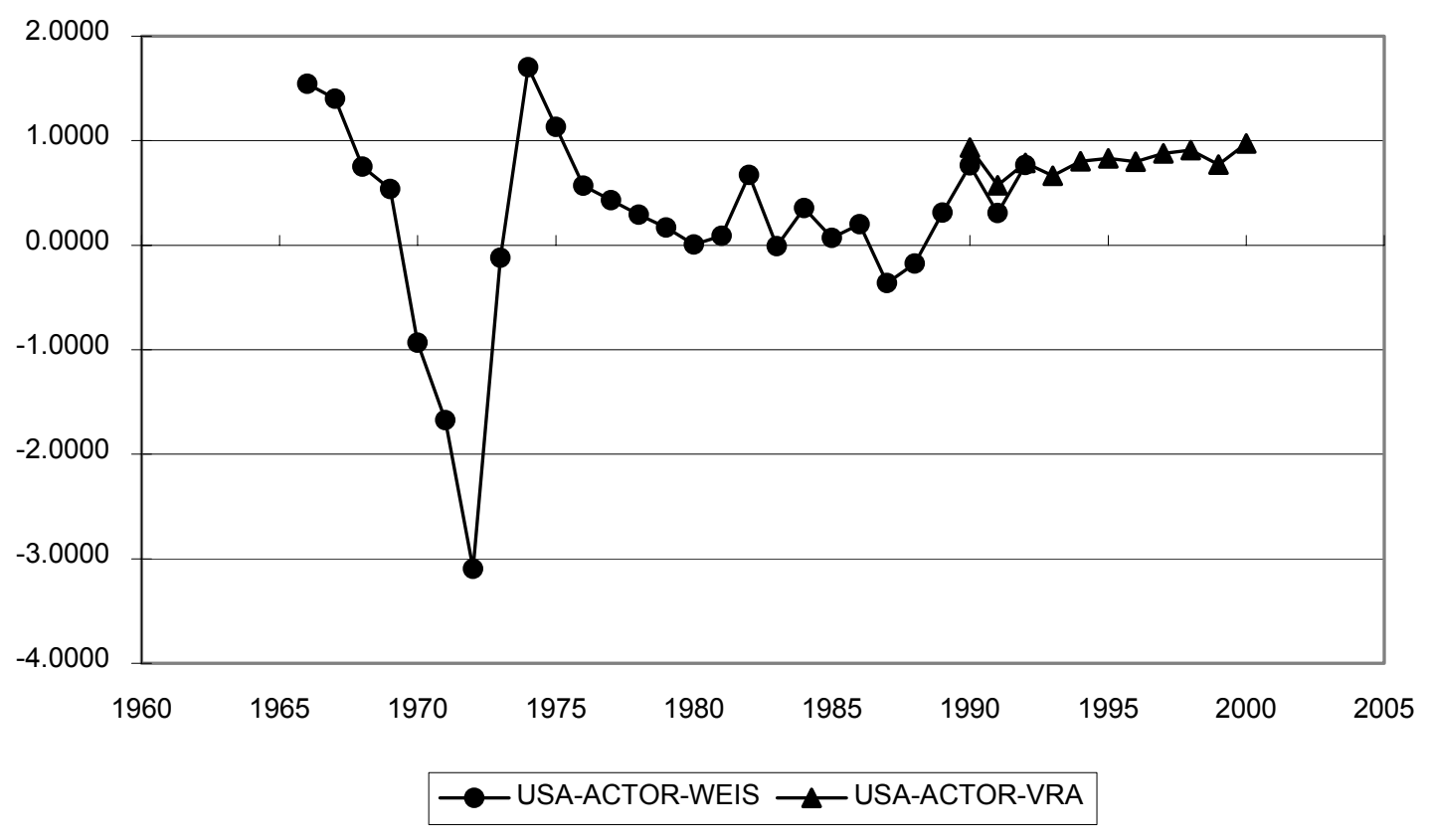

Figure 4

U.S. Conflict Based On WEIS and VRA 


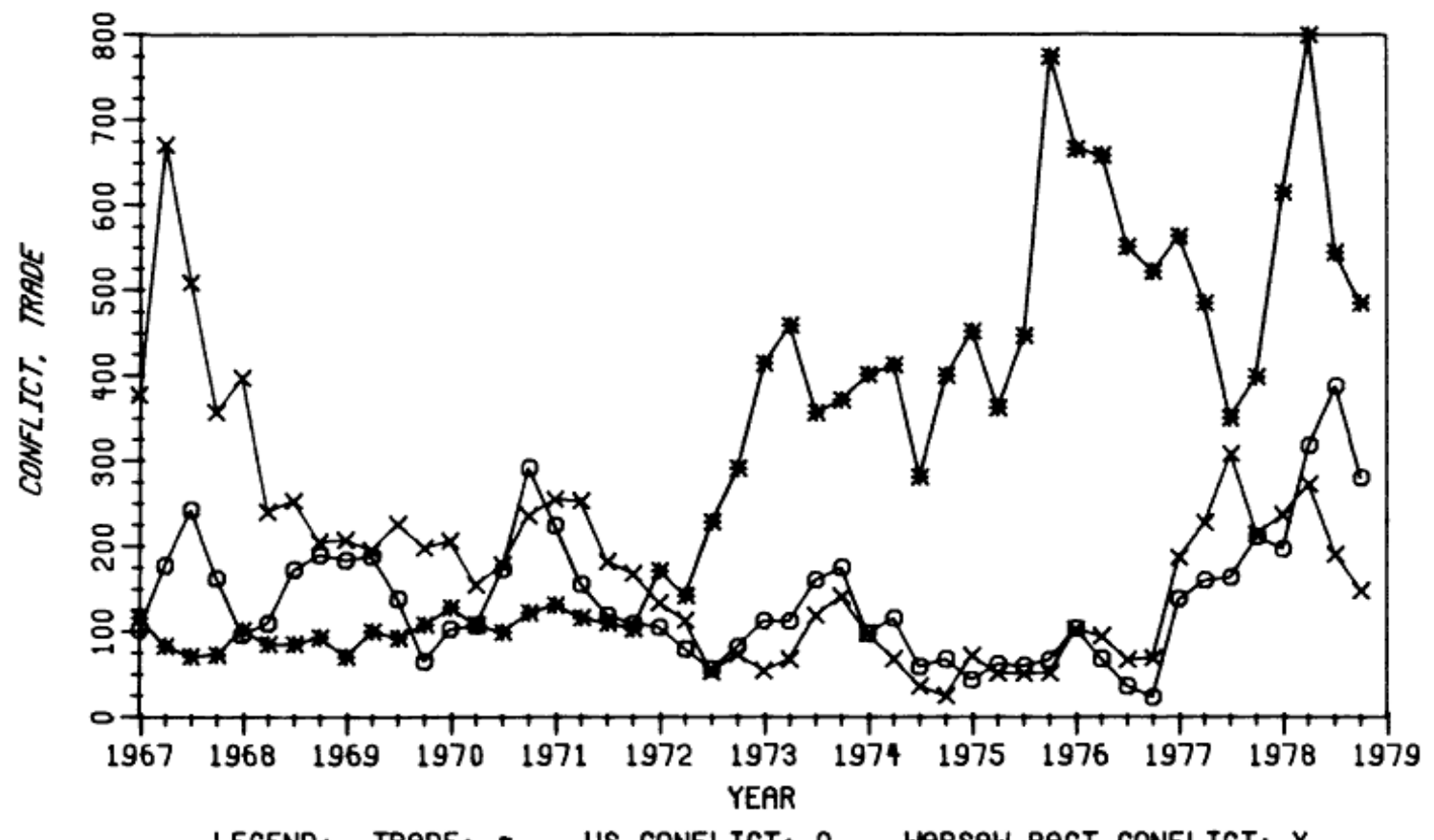

LEGEND: TRADE: - US CONFLICT: 0 HARSAW PACT CONFLICT: $X$

Figure 5

US-Warsaw Pact Trade and Conflict 1967-1978 (quarterly data)

Source: Gasiorowski and Polachek (1982) 


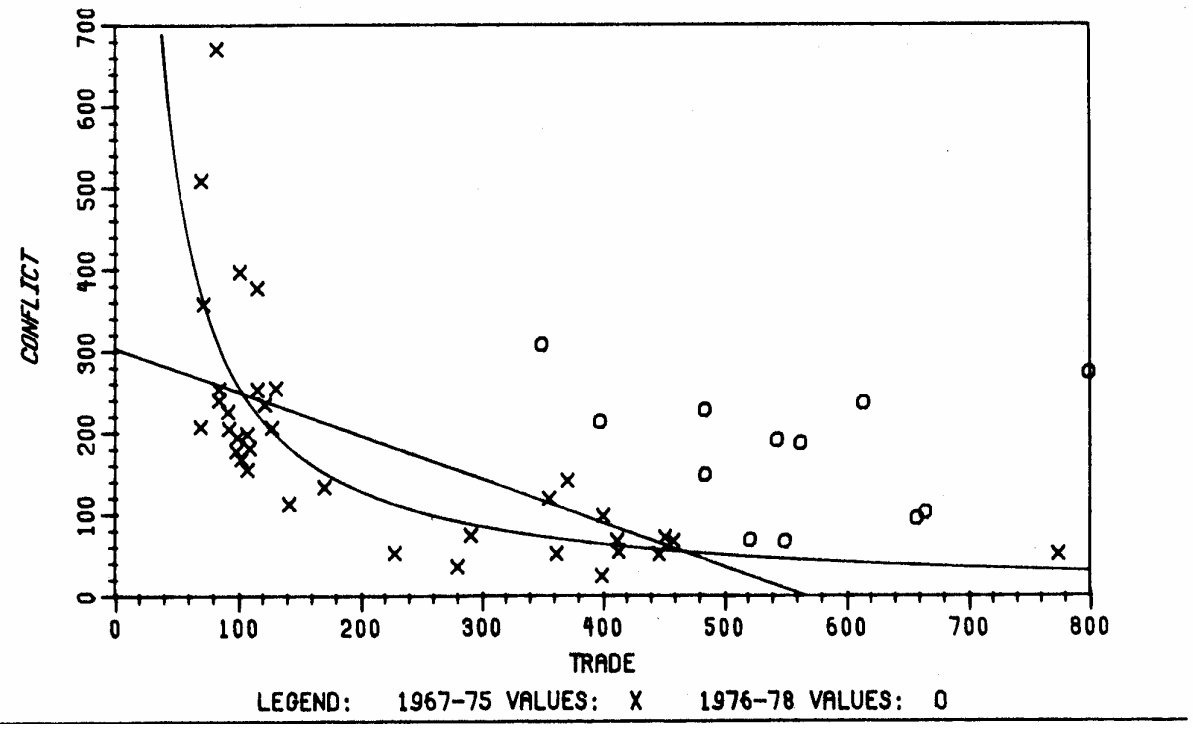

Figure 6

Cross-Sectional U.S.-Warsaw Pact Trade and Conflict Relation

Source: Gasiorowski and Polachek (1982) 


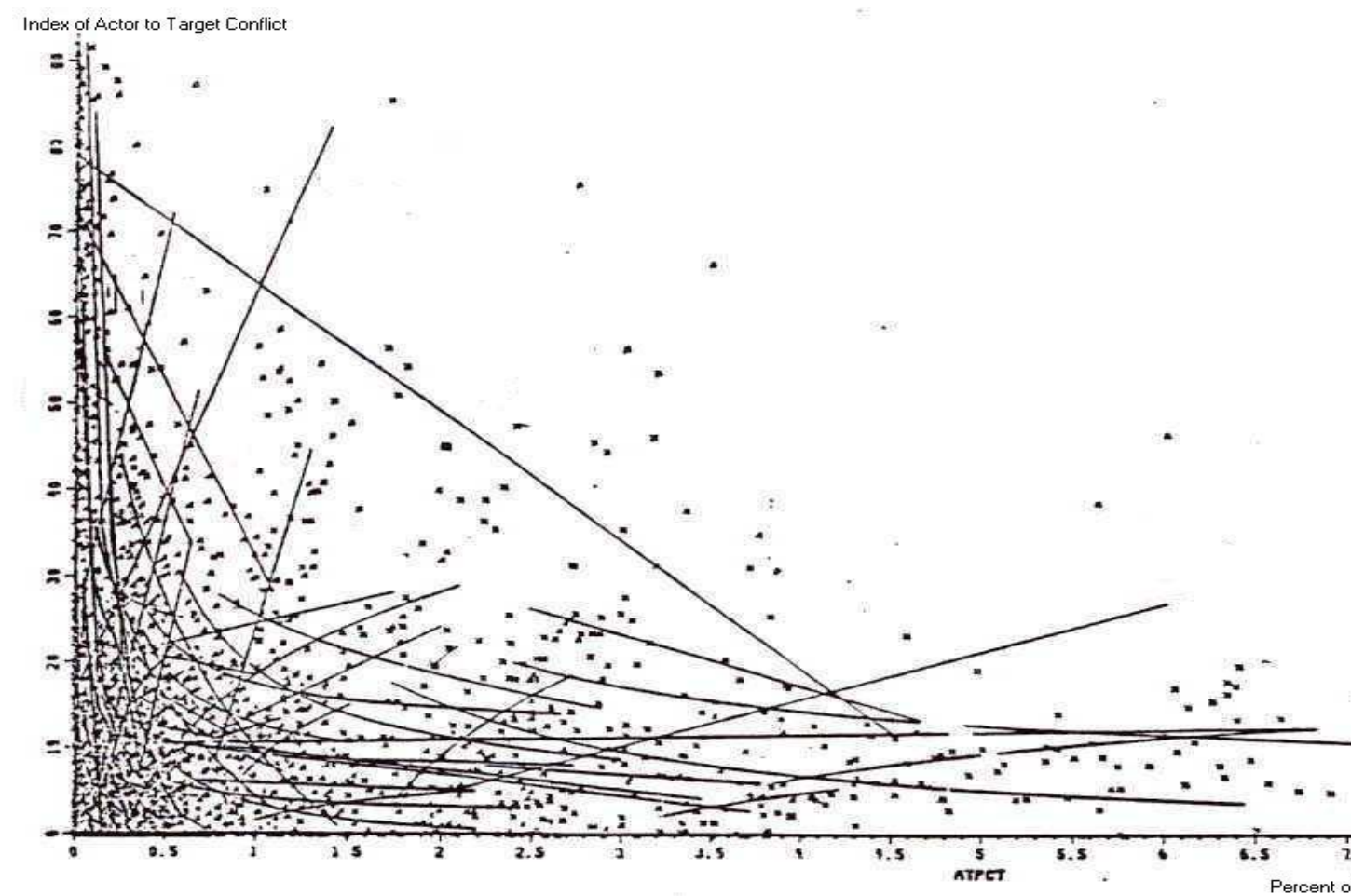

Figure 7

Country Specific Trade-Conflict Relationships: U.S. as Actor Source: Polachek (2002b) 


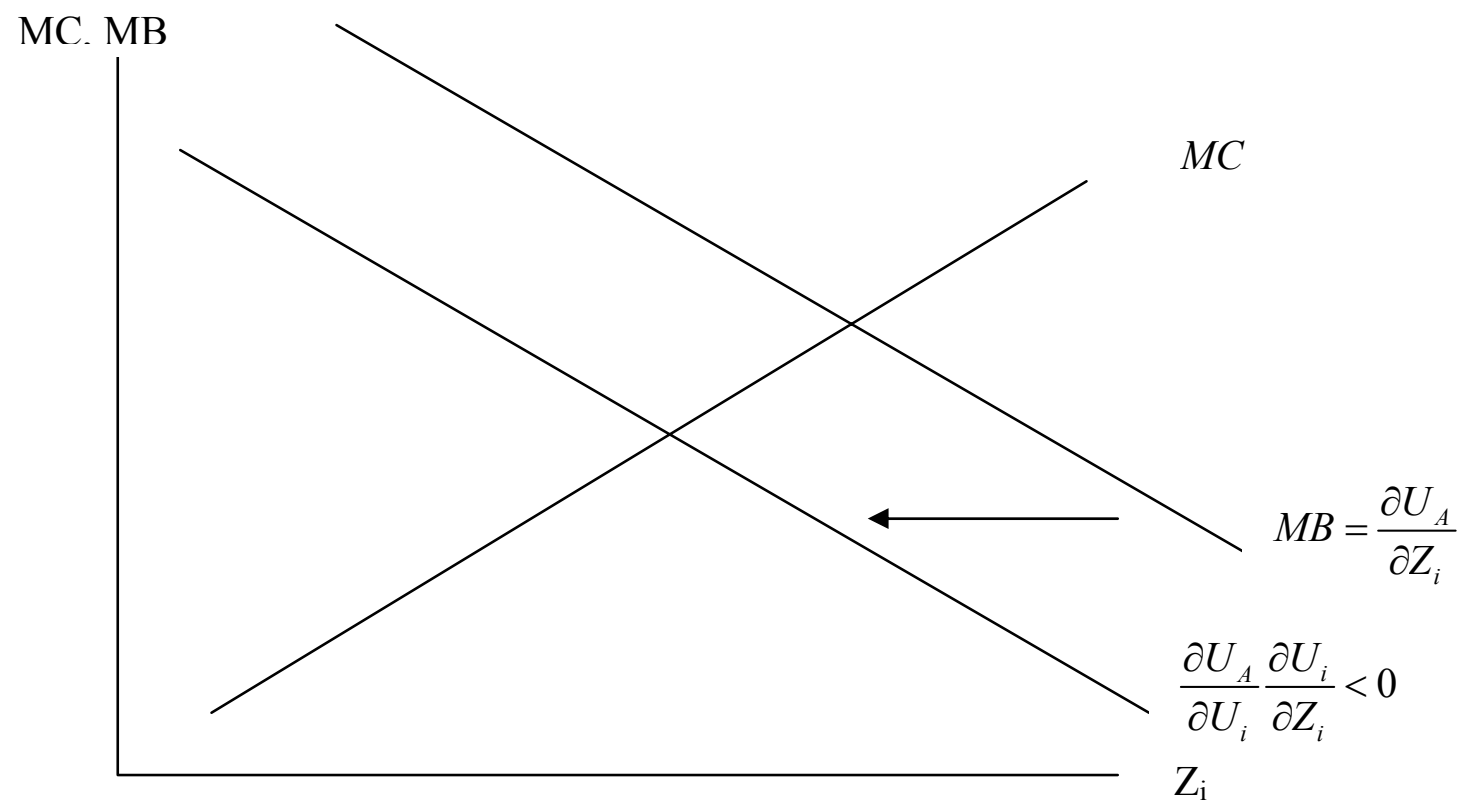

Figure 8

Interaction With A Friend 


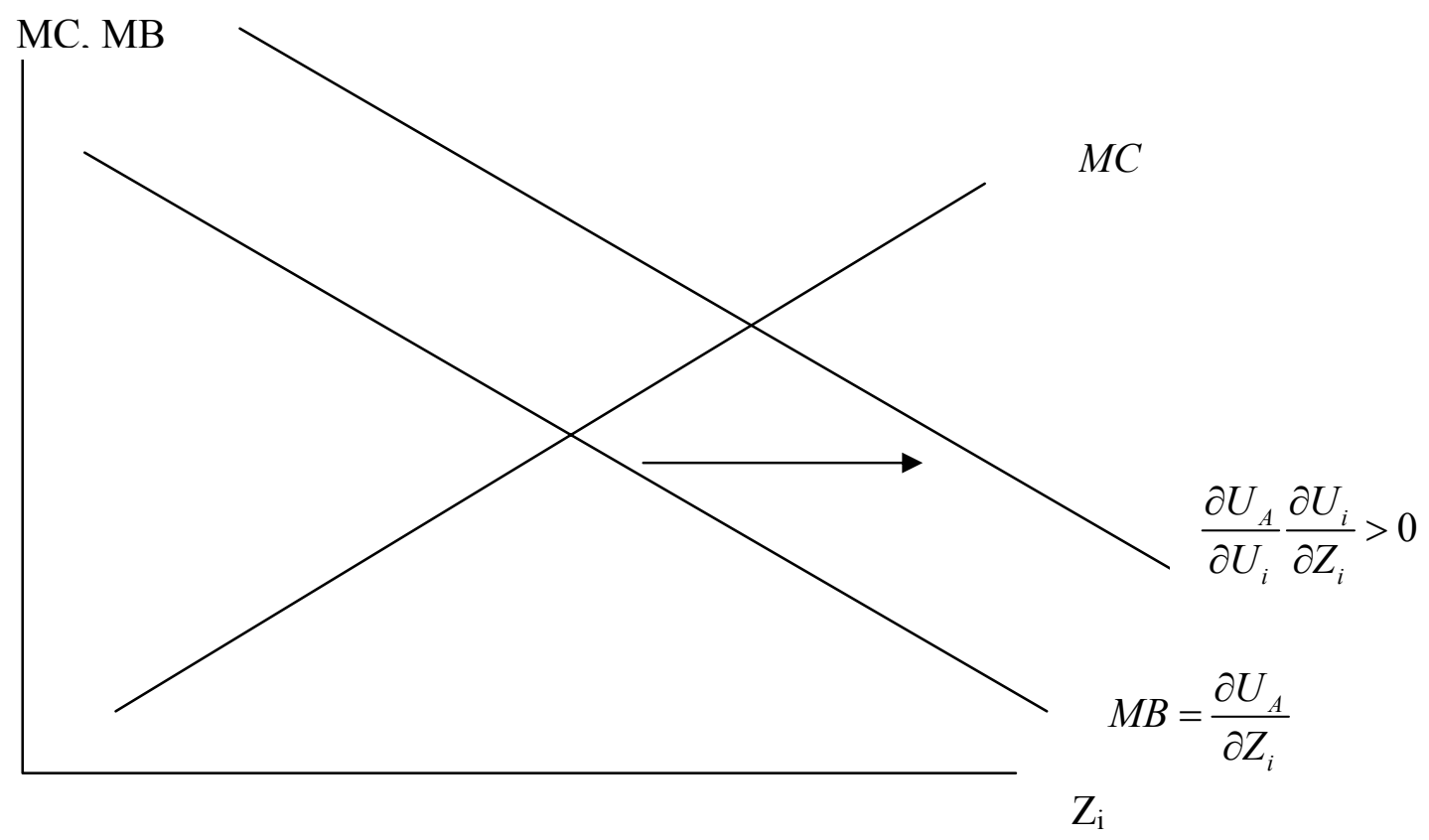

Figure 9

Interaction with a Rival 


\section{Table 1}

\section{Scale Weights for COPDAB*}

\begin{tabular}{|c|c|c|}
\hline SCALE POINT & DESCRIPTION & WEIGHTED VALUE \\
\hline 15 & Extensive War Acts & 102 \\
\hline 14 & Limited War Acts & 65 \\
\hline 13 & Small Scale Military Acts & 50 \\
\hline 12 & Political-Military Hostile Actions & 44 \\
\hline 11 & Diplomatic-Economic Hostile Actions & 29 \\
\hline 10 & Strong Verbal Hostile Expressions & 16 \\
\hline 9 & Mild Verbal Hostile Expressions & 6 \\
\hline 8 & Neutral Acts & 1 \\
\hline 7 & Minor Official Exchanges & 6 \\
\hline 6 & Official Verbal Support & 10 \\
\hline 5 & Cultural or Scientific Agreements & 14 \\
\hline 4 & Non-military Agreements & 27 \\
\hline 3 & Military Support & 31 \\
\hline 2 & Major Strategic Alliance & 47 \\
\hline 1 & Voluntary Unification & 92 \\
\hline
\end{tabular}

Source: Azar (1980). 
Table 2: Goldstein Weighting Scale for Events Reported in WEIS and VRA

\begin{tabular}{|c|c|c|c|c|c|}
\hline Goldstein & IDEA & Definition & Goldstein & IDEA & Definition \\
\hline-8.3 & 072 & Extend military aid & 2.8 & 12 & Accuse \\
\hline-7.6 & 074 & rally support & 3 & 161 & warn \\
\hline-7.6 & 073 & extend humanitarian aid & 3 & 16 & warn \\
\hline-7.4 & 071 & extend economic aid & 3.4 & 122 & denounce or denigrate \\
\hline-6.5 & 081 & make substantial agreement & 3.8 & 194 & halt negotiations \\
\hline-5.4 & 064 & improve relations & 4 & 1134 & break law \\
\hline-5.2 & 0523 & promise humanitarian support & 4 & 1132 & disclose information \\
\hline-5.2 & 0522 & promise military support & 4 & 1131 & political flight \\
\hline-5.2 & 0521 & promise economic support & 4 & 113 & defy norms \\
\hline-5.2 & 052 & promise material support & 4 & 1123 & veto \\
\hline-4.8 & 083 & collaborate & 4 & 1122 & censor media \\
\hline-4.8 & 08 & agree & 4 & 1121 & impose curfew \\
\hline-4.7 & 05 & promise & 4 & 112 & refuse to allow \\
\hline-4.5 & 051 & promise policy or non-material support & 4 & 111 & reject proposal \\
\hline-3.5 & 0432 & forgive & 4 & 11 & reject \\
\hline-3.5 & 04 & endorse or approve & 4.4 & 2122 & political arrest and detention \\
\hline-3.4 & 093 & ask for material aid & 4.4 & 2121 & criminal arrest and detention \\
\hline-3.4 & 092 & solicit support & 4.4 & 212 & arrest and detention \\
\hline-3.4 & 043 & empathize & 4.4 & 171 & non-specific threats \\
\hline-3.4 & 041 & praise & 4.5 & 1963 & administrative sanctions \\
\hline-3 & 082 & agree or accept & 4.5 & 1961 & strike \\
\hline-2.9 & 065 & ease sanctions & 4.5 & 196 & strikes and boycotts \\
\hline-2.8 & 054 & assure & 4.5 & 19 & sanction \\
\hline-2.8 & 033 & host meeting & 4.9 & 151 & demand \\
\hline-2.5 & 062 & extend invitation & 4.9 & 15 & demand \\
\hline-2.2 & 0655 & relax curfew & 5 & 201 & expel \\
\hline-2.2 & 0654 & demobilize armed forces & 5 & 20 & expel \\
\hline-2.2 & 0653 & relax administrative sanction & 5.2 & 1813 & protest defacement and art \\
\hline-2.2 & 0652 & relax censorship & 5.2 & 1812 & protest procession \\
\hline-2.2 & 0651 & observe truce & 5.2 & 1811 & protest obstruction \\
\hline-2.2 & 0632 & evacuate victims & 5.2 & 181 & protest demonstrations \\
\hline-2.2 & 063 & provide shelter & 5.6 & 193 & reduce or stop aid \\
\hline-2.2 & 06 & grant & 5.8 & 172 & sanctions threat \\
\hline-2.2 & 0431 & apologize & 6.4 & 175 & non-military force threats \\
\hline-2 & 013 & acknowledge responsibility & 6.4 & 17 & threaten \\
\hline-1.9 & 066 & release or return & 6.8 & 2112 & guerrilla seizure \\
\hline-1.9 & 032 & travel to meet & 6.8 & 2111 & police seizure \\
\hline-1.6 & 0933 & ask for humanitarian aid & 6.8 & 21 & seize \\
\hline-1.6 & 0932 & ask for military aid & 6.9 & 183 & control crowds \\
\hline-1.6 & 0931 & ask for economic aid & 6.9 & 1814 & protest altruism \\
\hline-1.6 & 09 & request & 6.9 & 18 & protest \\
\hline-1.5 & 1011 & offer peace proposal & 6.9 & 174 & give ultimatum \\
\hline-1.5 & 101 & peace proposal & 7 & 2231 & military clash \\
\hline-1.5 & 03 & consult & 7 & 195 & break relations \\
\hline-1.2 & 102 & call for action & 7 & 1734 & threaten military war \\
\hline-1.1 & 01 & yield & 7 & 1733 & threaten military occupation \\
\hline-1 & 031 & discussions & 7 & 1732 & threaten military blockade \\
\hline-0.8 & 10 & propose & 7 & 1731 & threaten military attack \\
\hline-0.6 & 012 & yield position & 7 & 173 & military force threat \\
\hline-0.6 & 011 & yield to order & 7.6 & 1827 & military border violation \\
\hline-0.1 & 091 & ask for information & 7.6 & 1826 & military border fortification \\
\hline-0.1 & 024 & optimistic comment & 7.6 & 1825 & military mobilization \\
\hline 0 & 99 & sports contest & 7.6 & 1824 & military troops display \\
\hline 0 & 98 & $A$ and $E$ performance & 7.6 & 1823 & military naval display \\
\hline 0 & 97 & accident & 7.6 & 1821 & military alert \\
\hline 0 & 96 & natural disaster & 7.6 & 182 & military demonstration \\
\hline 0 & 95 & human death & 8.3 & 224 & riot or political turmoil \\
\hline 0 & 94 & human illness & 8.7 & 221 & bombings \\
\hline 0 & 72 & animal death & 9.2 & 2236 & military seizure \\
\hline 0 & 27 & economic status & 9.2 & 2123 & abduction \\
\hline 0 & 26 & adjust & 9.2 & 211 & seize possession \\
\hline 0 & 25 & vote & 9.6 & 2228 & assassination \\
\hline 0 & 24 & adjudicate & 9.6 & 2227 & guerrilla assault \\
\hline 0 & 2321 & government default on payments & 9.6 & 2226 & paramilitary assault \\
\hline 0 & 2312 & private transactions & 9.6 & 2225 & torture \\
\hline 0 & 2311 & government transactions & 9.6 & 2224 & sexual assault \\
\hline 0 & 231 & transactions & 9.6 & 2223 & bodily punishment \\
\hline 0 & 23 & economic activity & 9.6 & 2222 & shooting \\
\hline 0.1 & 094 & ask for protection & 9.6 & 2221 & beatings \\
\hline 0.1 & 022 & pessimistic comment & 9.6 & 222 & physical assault \\
\hline 0.1 & 021 & decline comment & 9.6 & 22 & force \\
\hline 0.1 & 02 & comment & 10 & 2237 & biological weapons use \\
\hline 0.9 & 141 & deny responsibility & 10 & 2235 & assault \\
\hline 1 & 14 & deny & 10 & 2234 & military occupation \\
\hline 1.1 & 0631 & grant asylum & 10 & 2233 & coups and mutinies \\
\hline 2.2 & 192 & reduce routine activity & 10 & 2232 & military raid \\
\hline 2.2 & 121 & criticize or blame & 10 & 223 & military engagements \\
\hline 2.4 & 132 & formally complain & & & \\
\hline 2.4 & 131 & informally complain & & & \\
\hline 2.4 & 13 & complain & & & \\
\hline
\end{tabular}

Source: King and Lowe (2003), pp 622-623. 
Table 3: Descriptive Statistics:

(Mean Variable Values)

\begin{tabular}{|l|c|c|c|}
\hline \multicolumn{1}{|c|}{ Variables } & $\begin{array}{c}\text { COPDAB } \\
\mathbf{( 1 9 4 8 - 7 8 )}\end{array}$ & $\begin{array}{c}\text { WEIS } \\
\mathbf{( 1 9 6 6 - 9 2 )}\end{array}$ & $\begin{array}{c}\text { VRA } \\
\mathbf{( 1 9 9 0 - 2 0 0 0 )}\end{array}$ \\
\hline Trade & 205.0965 & 2007.158 & 2376.502 \\
Maximum Power & .0274 & .0571 & .0311 \\
Minimum Power & .0029 & .0057 & .0041 \\
Joint Democracy & 105.4562 & 144.09 & 229.0424 \\
Political Dissimilarity & 7.4171 & 8.7586 & 6.8849 \\
Contiguity Dummy & .1391 & .2321 & .1523 \\
Major Power Dummy & .1851 & .4656 & .2587 \\
GATT/WTO Membership Dummy & .3382 & .4295 & .5732 \\
\hline Observations & 76,705 & 15,702 & 36,434 \\
\hline
\end{tabular}

Computed for country pairs (dyads) contained in COPDAB, WEIS, and VRA.

Variable Definitions:

Trade: Dyadic Trade Volume in Millions of Current US Dollars;

Maximum Power: Composite Index of National Capabilities (CINC) Score (ranging from 0 to 1)

of the Stronger Country within Dyads (See: Correlates of War Project National Material

Capabilities Data Documentation Version 3.0, Last update: May 2005); Minimum Power: CINC

Score of the Weaker Country within Dyads; Joint Democracy: Multiplication of Regime Type

Scores (obtained from the Polity IV Survey) within Dyads (1-441); Political Dissimilarity:

Distance between Regime Type Scores within Dyads (0-20); Contiguity Dummy: One if Borders

by Land or by Water within 400 Miles, Zero Otherwise; Major Power Dummy: One if China,

France, Great Britain, Russia/USSR or United States is within Dyads, Zero Otherwise;

GATT/WTO Membership: One if Both Countries were GATT or WTO Members, Zero

Otherwise. 
Table 4

The Trade-Conflict Relation

\begin{tabular}{|c|c|c|c|}
\hline Variable & Mean $^{1}$ & Coefficient $^{2}$ & Elasticity $^{3}$ \\
\hline Constant & & $\begin{array}{l}-50.49 \\
(3.12)\end{array}$ & \\
\hline Dyadic Trade Elasticity & $\begin{array}{l}0.83 \\
(.04)\end{array}$ & $\begin{array}{l}37.62 \\
(2.63)\end{array}$ & 0.47 \\
\hline Exports (billions US\$) & $\begin{array}{l}4.13 \\
(0.67)\end{array}$ & $\begin{array}{l}-4.49 \\
(4.47)\end{array}$ & $\begin{array}{l}0.28 \\
0.28\end{array}$ \\
\hline Imports (billions of US\$) & $\begin{array}{l}4.02 \\
(0.67)\end{array}$ & $\begin{array}{l}-8.21 \\
(-6.86)\end{array}$ & 0.50 \\
\hline GNP (actor) & $\begin{array}{l}232.8 \\
(26.1)\end{array}$ & $\begin{array}{l}0.0178 \\
(0.46)\end{array}$ & \\
\hline GNP (actor) - GNP (target) & $\begin{array}{l}3.93 \\
(39.0)\end{array}$ & $\begin{array}{l}-.056 \\
(2.20)\end{array}$ & 0.003 \\
\hline Net Conflict & $\begin{array}{l}-66.63 \\
(9.66)\end{array}$ & & \\
\hline $\begin{array}{l}\mathrm{R}^{2} \\
\text { Number of Observations }\end{array}$ & & $\begin{array}{l}0.35 \\
178\end{array}$ & \\
\hline
\end{tabular}

${ }^{1}$ Standard error of mean in parentheses

${ }^{2} \mathrm{t}$-values in parentheses

${ }^{3}$ computed at mean values

The dependent variable is net-conflict computed from COPDAB. Source: Polachek and McDonald (1992) 


\section{Table 5}

Three-Stage Least Square Estimation of FDI-Conflict Relationship-FDI Inflow

(Z-Score in parentheses)

\begin{tabular}{|c|c|c|}
\hline & \multicolumn{2}{|c|}{ Dependent Variables } \\
\hline Independent Variables & $\begin{array}{c}\text { Total } \\
\text { (Net cooperation) }\end{array}$ & FDI Inflow \\
\hline Constant & $\begin{array}{l}-.260 \\
(-0.16)\end{array}$ & $\begin{array}{l}-1827.978 * * * \\
(-4.61)\end{array}$ \\
\hline FDI Inflow & $\begin{array}{l}.014 * * * \\
(7.72)\end{array}$ & \\
\hline GDP Actor & $\begin{array}{l}9.03 \mathrm{e}-06 * * * \\
(14.77)\end{array}$ & $\begin{array}{l}-4.36 \mathrm{e}-05 \\
(-1.35)\end{array}$ \\
\hline GDP Target & $\begin{array}{l}6.18 \mathrm{e}-06 * * * \\
(11.05)\end{array}$ & $\begin{array}{l}-3.57 \mathrm{e}-07 \\
(-0.01)\end{array}$ \\
\hline Power Ratio & $\begin{array}{l}-.142 * * * \\
(-8.59)\end{array}$ & \\
\hline Joint Democracy & $\begin{array}{l}-.014 * * * \\
(-3.68)\end{array}$ & \\
\hline Contiguity & $\begin{array}{l}7.103 * * * \\
(4.67)\end{array}$ & \\
\hline Total (Net Cooperation) & & $\begin{array}{l}23.000 * * * \\
(8.59)\end{array}$ \\
\hline WTO & & $\begin{array}{l}128.576^{*} \\
(1.97)\end{array}$ \\
\hline Population Actor & & $\begin{array}{l}3.91 \mathrm{e}-04 * * * \\
(3.36)\end{array}$ \\
\hline Population Target & & $.001 * * *$ \\
\hline Telephone Mainlines Actor & & $\begin{array}{l}.442 * * \\
(2.75)\end{array}$ \\
\hline Telephone Mainlines Target & & $\begin{array}{l}.357 * \\
(2.35)\end{array}$ \\
\hline School Enrollment, Primary Actor & & $4.169^{*}$ \\
\hline School Enrollment, Primary Target & & $\begin{array}{l}(2.02) \\
1.772\end{array}$ \\
\hline School Enrollment, Secondary Actor & & $(0.83) * *$ \\
\hline School Enrollment, Secondary Target & & $\begin{array}{l}(2.87) \\
5.873 * * *\end{array}$ \\
\hline & & $(4.68)$ \\
\hline Gross Capital Formation Actor & & -2.761 \\
\hline Gross Capital Formation Target & & $\begin{array}{l}(-0.83) \\
-5.200\end{array}$ \\
\hline & & $(-1.53)$ \\
\hline$R$ Squared & .2730 & .1756 \\
\hline$N$ & 5449 & 5449 \\
\hline
\end{tabular}

Note: $* * * \mathrm{p}<.001 ; * * \mathrm{p}<.01 ; * \mathrm{p}<.05$.

Source: Polachek, Seiglie and Xiang (2005) 


\section{Endnotes}

1. Progress on this latter work is reported in Polachek et al. (1999). Also see Dorussen (1999), and Hegre (1999) for other analyses of trade and conflict in a multi-country environment.

2. This section is based on Polachek (1994a) who describes conflict as trade gone awry. 3. See Blainey (1988), Sayrs (1990), McMillan (1997), Barbieri and Schneider (1999), Reuveny (1999), Mansfield and Pollins (2001 and 2003), and Schneider, et al. (2003) for recent surveys on the literature emanating from the trade (interdependence) - conflict model. See Mansfield (2004) for classic reading on the topic.

4. Polachek (1980) first formalized this model. A more general derivation is given in Martin et al. (2005). Also see Caruso (2006).

5. In this paper we ignore how special interest groups affect trade. See Grossman and Helpman (2002) for valuable insights here.

6. At this point we assume no direct costs of conflict.

7. Barbieri (2002) is the prime advocate of this approach.

8. Also during the late 1970s and early 1980s, the United States Department of State, Department of Defense and various intelligence agencies as well as private political consulting firms such as CACI Inc. collected events data. In this regard, in 1971, the Department of State's Foreign Relations Indicator Project (FRIP) coded events data for a small set of states. Similarly, early in the Reagan administration, the Pentagon's Defense Advanced Research Project Agency (DARPA) and the National Security Council staff in the White House supported a large-scale project to develop events data for crisis forecasting. These efforts apparently had little long-term impact on the formulation of foreign policy. Domestic and international event data were also collected by Rummel (1975) and Taylor and Hudson (1972), Hermann, et al. (1973) as well as Gurr (1974). However, their focus was limited [see Philip Schrodt (1995)]. For a more complete listing of conflict data see: http://www.pcr.uu.se/research/UCDP/confliktdatasetcatalog.pdf. 9. This section borrows heavily from Gasiorowski and Polachek (1982). In addition, Polachek (2002a) performed the same analysis for US-China with similar results. Also see Reuveny and Kang (1996) for additional evidence.

10. They also replicated the analysis for the US and Soviet Union. However, these results were not reported.

11. The technique Polachek and Kim (1994b) develop for estimating gender wage differences could be applied to estimate such individual-specific slope coefficients.. 12. This section is based on research with Judith McDonald. See Polachek and McDonald (1992).

13. Haas and Turner (1988) present information on three broad merchandise trade categories for 14 OECD countries. We will refer to these estimates shortly. 14. This section borrows heavily from Polachek and Robst (1998). See Polachek (2002b) and Polachek (2004) for an application regarding union membership and strike activity. 15. There are other explanations. For example, Levy and Razin (2004) use a game theoretic model to show that information asymmetries and strategic complements cause the strategic interaction between two democracies to differ from that of any other dyad. On the other hand Zeng (2004) uses game theory to show how trade competitiveness between democracies creates stronger domestic pressure for the use of threat tactics, 
increasing the risk of trade war. Hess and Orphanides (2001) argue that poorly performing incumbent leaders seek to hold on to power thereby generating an incentive to initiate conflict.

16. See MacMillan (2003) for an extensive survey on this issue covering over 25 articles on this topic.

17. See Froot (1995), Rayome and Baker (1995), Saggi (2002), and Blonigen (2005) for surveys of the literature on the determinants of FDI.

18. This section borrows heavily from Polachek (2003). 